This is the peer reviewed version of the following article: Gupta, Sushil, Starr, Martin, Zanjirani Farahani, Reza and Matinrad, Niki (2016) Disaster management from a POM perspective : mapping a new domain. Production and Operations Management, 25(10), pp. 1611-1637, which has been published in final form at https://doi.org/10.1111/ poms.12591. This article may be used for non-commercial purposes in accordance with Wiley Terms and Conditions for Use of Self-Archived Versions. 


\title{
Disaster Management from a POM Perspective: Mapping a New Domain
}

\begin{abstract}
We have reviewed disaster management research papers published in major operations management, management science, operations research, supply chain management and transportation/ logistics journals. In reviewing these papers our objective is to assess and present the macro level "architectural blue print" of disaster management research with the hope that it will attract new researchers and motivate established researchers to contribute to this important field. The secondary objective is to bring this disaster research to the attention of disaster administrators so that disasters are managed more efficiently and more effectively. We have mapped the disaster management research on the following five attributes of a disaster: (1) Disaster Management Function (decision making process, prevention and mitigation, evacuation, humanitarian logistics, casualty management, and recovery and restoration), (2) Time of Disaster (before, during and after), (3) Type of Disaster (accidents, earthquakes, floods, hurricanes, landslides, terrorism and wildfires etc.), (4) Data Type (Field and Archival data, Real data and Hypothetical data), and (5) Data Analysis Technique (bidding models, decision analysis, expert systems, fuzzy system analysis, game theory, heuristics, mathematical programming, network flow models, queueing theory, simulation and statistical analysis). We have done cross tabulations of data among these five parameters to gain greater insights in disaster research. Recommendations for future research are provided.
\end{abstract}

Key words: Disaster Management, Humanitarian Logistics, Supply Chains, Prevention and Mitigation, Evacuation, Casualties, Recovery, Restoration, Federal Emergency Management Agency (FEMA). 


\section{INTRODUCTION}

The number of disasters and their severity that are being reported and studied around the globe is increasing. As a result, the management of such disasters has drawn attention of professionals from all fields: business executives, engineers, scientists, IT experts, doctors and social scientists. Managing disasters has become not only a multi-discipline but also a multiagency endeavor that includes public and private organizations, local, national and international governments, and nonprofit humanitarian organizations. Managing disasters is unlike managing a business organization because the goals and objectives are different. The objective in disaster management is not profit making; rather it is saving lives and reducing human suffering. The word disaster includes natural disasters (hurricanes, tornadoes, floods, tsunamis etc.) as well as manmade disasters (due to terror and error). Terror subsumes-terrorist activities and errors lead to industrial (including power plants) and transportation (air, rail and ship) accidents. The terror category embodies the use of intelligence with malevolent intent to inflict serious destruction.

Research in the management of disasters from a Production and Operations Management (POM) perspective is relatively new as revealed by our findings. The Production and Operations Management journal has created a department of "Disaster Management" to encourage research in this field in February, 2015. The objective of this paper is to assess and present the macro level "architectural blue print" of disaster management research with the hope that it will attract new researchers and motivate established researchers to contribute to this important field. The secondary objective is to bring this disaster research to the attention of disaster administrators so that disasters are managed more efficiently and more effectively. The review is based on research papers published in major operations management, management science, operations research, supply chain management and transportation/ logistics journals. For the sake of brevity, from this point onwards we will use the term POM to represent all the listed fields.

\subsection{Roadmap for Reading the Paper}

The roadmap for reading this paper (shown in Figure 1) includes in Section 1 a discussion of the attributes of a disaster, the selection of the journals, the selection of the papers to be reviewed and the scope and limitations of this study. In Section 2 we have discussed the chronology of growth in disaster management research. The scheme for classifying the selected papers is given 
in Section 3 in which we discuss various administrative functions performed in managing a disaster, types of disasters, time phases of disasters, types of data and data analysis techniques. A review of the research studies that focus on administrative functions is the subject matter of section 4. In Section 5 we have cross tabulated and analyzed the data among the attributes of a disaster. Section 6 focusses on the utilization of disaster research by disaster administrators. The summary, conclusions and directions for future research are given in Section 7 which precedes the list of references.

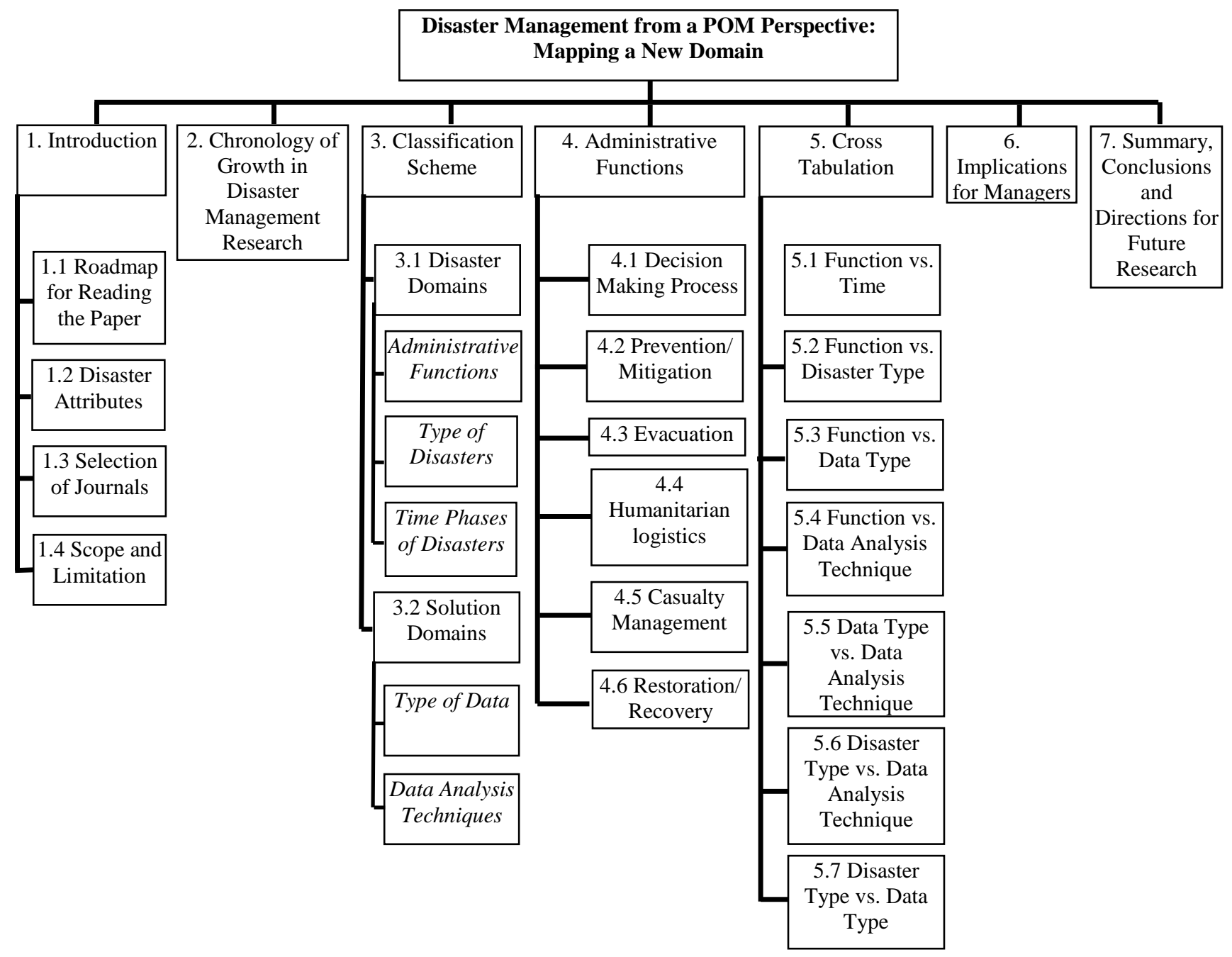

Figure 1: The roadmap for reading this paper. 


\subsection{Disaster Attributes}

For mapping the disaster management field, we have identified five attributes of a disaster based on the papers reviewed: 1. Disaster Management Functions (decision making process, prevention and mitigation, evacuation, humanitarian logistics, casualty management, and recovery and restoration), 2. Time of Disaster (before, during and after), 3. Type of Disaster (a partial list includes accidents, earthquakes, floods, hurricanes, landslides, terrorism and wildfires etc.), 4. Data Type (Field and Archival data, Real data and Hypothetical data), and 5. Data Analysis Techniques (bidding models, decision analysis, expert systems, fuzzy system analysis, game theory, heuristics, mathematical programming, network flow models, queueing theory, simulation and statistical analysis). We have also done cross tabulations of data among these five parameters in Section 5 to gain greater insights that can enhance disaster research.

In reviewing these papers and analyzing the data our objectives are two-fold: (1) to identify developments in disaster management research that can help administrators (practitioners) in managing disasters more efficiently and more effectively and (2) to provide directions for future researchers. This paper is expected to be a catalyst for motivating young as well as established researchers and helping them identify research domains within the broader context of disaster management.

\subsection{Selection of Journals}

The time period for this review is from 1957 to 2014 . The year 1957 was chosen as the starting year because that was the year when the first issue of Management Science was published. There were no other journals at that time in these fields. The major journals that are included in this study are listed below in alphabetical order.

1. Annals of Operations Research

2. Computers and Operations Research

3. Decision Sciences

4. Decision Support Systems

5. European Journal of Operational Research

6. IIE Transactions

7. International Journal of Operations \& Production Management
8. International Journal of Production Economics

9. International Journal of Production Research

10. Journal of Operations Management

11. Journal of Supply Chain Management

12. Journal of the Operational Research Society

13. Management Science 
14. Manufacturing \& Service Operations Management

15. Mathematical Programming

16. Mathematics of Operations Research

17. Naval Research Logistics

18. Operations Research

19. OR Spectrum

20. Production and Operations Management
21. Supply Chain Management: An International Journal

22. OMEGA: The International Journal of Management Science

23. Transportation Research Part B: Methodological

24. Transportation Research Part E: Logistics and Transportation Review 25. Transportation Science

In this paper we used Google Scholar as the search engine. For each journal any paper that had at least one of the following words in the entire text of the paper was considered a potential paper for this review: "disaster", “disasters", "apocalypse", "calamity", "cataclysm", "catastrophe”, "debacle", "tragedy", "crisis" and "crises". During the initial search and primary screening, 507 research papers with the abovementioned keywords were found. Each one of these papers was reviewed by all four authors independently using title, abstract and keywords. After several iterations of the selection process the authors agreed on the list of 267 papers that are reviewed in this paper. We did not include papers that deal with financial, organizational, and political crises; and disasters due to wars. We also did not include technical journals dealing with such subjects as epidemiology, building codes to withstand hurricane winds, engineering of earthquake resistant structures, how to build roads and bridges to withstand the forces of earthquakes, safe nuclear plants, engineering of levees, role of information technology and social media etc. Many of the "before" issues are likely to be treated in such specialty journals.

\subsection{Scope and Limitation}

The scope of this paper is to assess and present the macro level "architectural blue print" of disaster management research. We found 267 relevant papers for our research. The objective is not to analyze and synthesize the contributions of individual papers. Rather, we intend to create the macro-view of the disaster management domain. We want to look back, make an assessment and provide directions to potential researchers.

The scope of the search is limited to major POM journals because our audience includes primarily POM researchers. The disaster specific journals are not included because they do not belong to the POM domain. Examples of these journals include: Journal of Homeland Security and Emergency 
Management, Australian Journal of Emergency Management, Journal of Natural Disaster Science, Disasters, Disaster Prevention and Management: An International Journal, Journal of Business Continuity \& Emergency Planning. However, these may provide useful and practical topics for disaster management researchers.

\section{Chronology of Growth in Disaster Management Research}

The chronology of growth in disaster management research, between 1980 and 2010, has been documented by two survey papers (Altay and Green III 2006 and Galindo and Batta 2013). The time spans for these two survey papers are 1980-2004 and 2005-2010, respectively. The time span that our paper covers is from 1957 to 2014. Altay \& Green III (2006) include 109 articles in their survey; Galindo and Batta (2013) review 155 articles. The research sources used by these two papers were not limited to the 25 journals that we have used in the current survey. We found 267 papers in the 25 journals. The chronology of development is important because it is irregular and may correlate with factors that others will discover. We consider variability over time as part of our assessment of these papers as provided below.

Figure 2 gives the count of papers by journal and by year. In this table we aggregated the counts for years 1957 to 2000 because of the small number of papers published in these years. The top five journals with maximum number of papers include: European Journal of Operational Research (45) followed by Computers \& Operations Research (26), Decision Support Systems (23), Journal of the Operational Research Society (21), and OR spectrum (20). The numbers in parentheses show the paper counts. These 135 papers out of 267 papers, published in five journals, represent about 50\% of all papers. These journals are primarily Operations Research/Management Science journals. The three major journals that are considered primarily Production and Operations Management journals published 21 papers (7.86\% of total publications) that include Production and Operations Management (13), Manufacturing \& Service Operations Management (5) and Journal of Operations Management (3). Clearly main stream POM researchers have not paid much attention to disaster management. The Production and Operations Management journal has recently created a department of "Disaster Management" to encourage research in this field and fill this void. 
We did not find any relevant papers in Mathematical Programming, Mathematics of Operations Research and International Journal of Operations and Production Management. These journals were included in the list of 25 journals that we surveyed.

It may also be noted that special issues relating to disaster management were published by five journals. The years of publications and the editors of the special issues include: IIE Transactions (Jacobson et al., 2007), Computers \& Operations Research (Osei-Bryson and Joseph, 2009), International Journal of Production Economics (Boin et al., 2010), OR Spectrum (Doerner et al., 2011), and Production and Operations Management (Starr and Wassenhove, 2014).

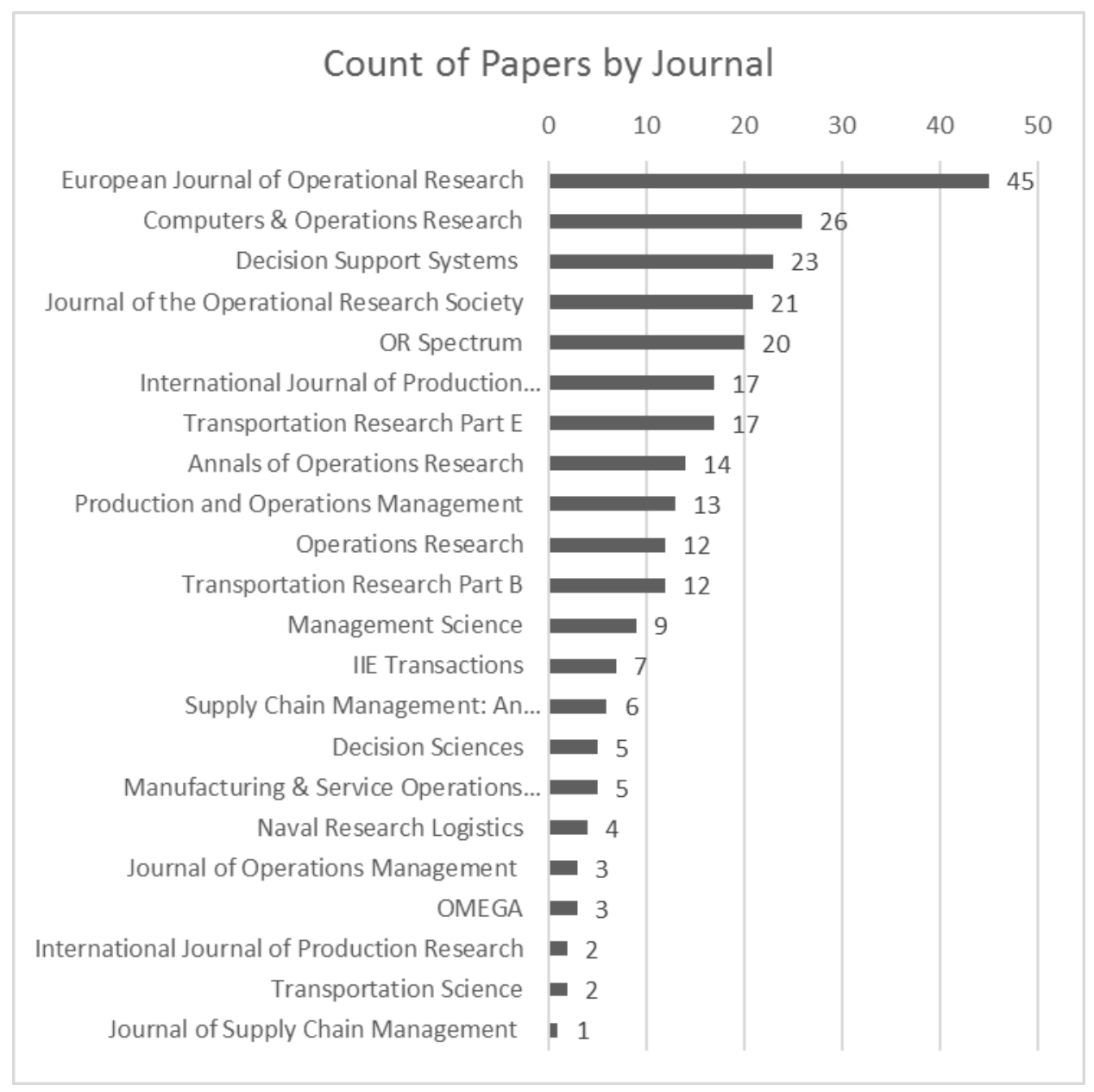

Figure 2: Count of papers reviewed by journal. 
To study the growth rate of disaster research literature we also used a 3-year moving average. Table 1 and Figure 3 depict the 3-year moving average of papers published on disaster management. Table 1 shows the moving average starting from year 2001. The 3-year moving average in 2008 was 10.00 (highest as compared to any previous year). Publication of 22 papers in 2007 made the moving average jump to 10.00 in 2008 . The 3 -year moving average continued to increase thereafter with a small reversal in 2011. This decline in 2011 was due to a decline in the number of papers in 2008 (13) and 2009 (11). The number of papers increased to 16 in 2010. The number of papers published in 2011, 2012, 2013 and 2014 were more than 31 in each year. The number of papers in 2014 was 49. These numbers clearly indicate a growing interest of POM researchers in disaster management.

The top five journals have published $50.56 \%$ of the papers. The European Journal of Operational Research is on the top and has 45 published papers which is $16.85 \%$ of these papers. Altay and Green III (2006) and Galindo and Batta (2013) also noted that EJOR is on the top of the list in the count of disaster management papers. On the contrary, Management Science and Operations Research have 9 (3.37\%) and 12 (4.49\%) papers respectively. We did not find any explanation for the small number of publications in these two leading tenure-rated journals.

Table 1: Three-year moving average of the count of papers published in all journals.

\begin{tabular}{|c|c|c|}
\hline \multicolumn{1}{|c|}{ Year } & Count & $\begin{array}{l}\text { Three-Year Moving } \\
\text { Average }\end{array}$ \\
\hline 2001 & 3 & 2.67 \\
\hline 2002 & 2 & 3.33 \\
\hline 2003 & 0 & 3.33 \\
\hline 2004 & 3 & 1.67 \\
\hline 2005 & 1 & 1.67 \\
\hline 2006 & 7 & 1.33 \\
\hline 2007 & 22 & 3.67 \\
\hline 2008 & 13 & 10.00 \\
\hline 2009 & 11 & 14.00 \\
\hline 2010 & 16 & 15.33 \\
\hline 2011 & 34 & 13.33 \\
\hline 2012 & 31 & 20.33 \\
\hline 2013 & 36 & 27.00 \\
\hline 2014 & 49 & 33.67 \\
\hline Total & 267 & \\
\hline
\end{tabular}




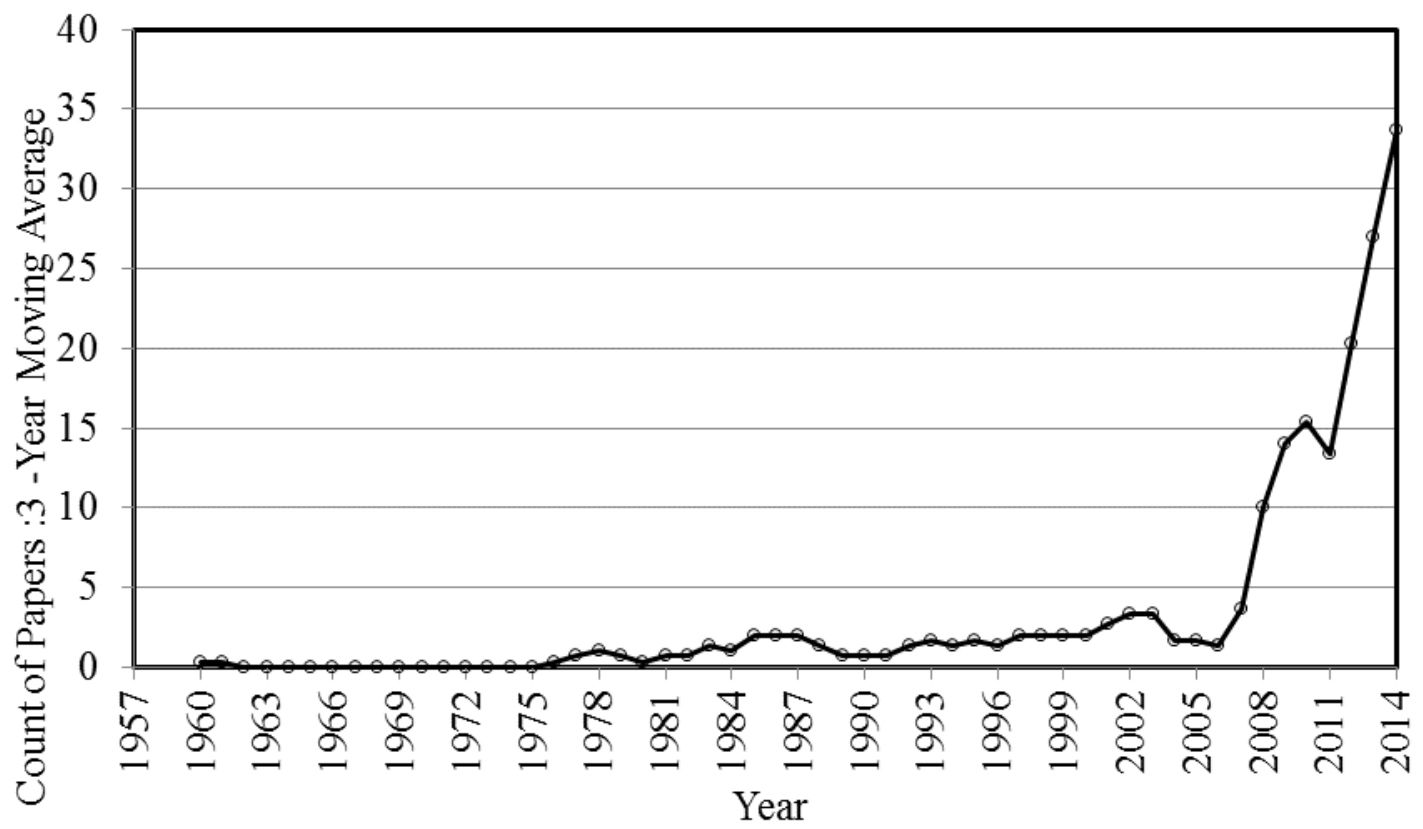

Figure 3: Three-year moving average of the count of all papers published in all journals.

\section{Classification Scheme}

The 267 papers that are being reviewed here revealed that there are three important parameters that describe a disaster scenario and two parameters that focus on the solutions to the problems. In this paper we call these Disaster Domains and Solution Domains as described below.

\subsection{Disaster Domains}

We have defined a disaster domain by the following three parameters: the function performed by the administrators, the type of disaster and the time phase of the disaster. All categories of this scenario are described below.

\section{Administrative Functions}

Most researchers tend to study a single aspect of disaster management which we describe as a "function". Similarly most administrators are generally responsible for managing one function. Therefore, "function" is an important defining parameter for studying disaster management research. Based on a review of the 267 papers, we have divided the papers in the following six functional 
categories: 1. Decision making process, 2. Prevention and Mitigation, 3. Evacuation, 4. Humanitarian Logistics, 5. Casualty Management, and 6. Restoration and Recovery. These functions are further subdivided into subcategories for a total of 33 subcategories as discussed in Section 4.

\section{Type of Disasters}

There are two major categories of disasters: manmade and natural.

Manmade: The manmade disasters are due to error or terror. The errors cause industrial accidents. Examples include nuclear accidents, HAZMAT (chemical spills, oil spills etc.), transportation (air, rail and ship) accidents etc. Terrorist activity embodies the use of intelligence with malevolent intent to inflict serious destruction. The manmade disasters are preventable.

Natural: Most natural disasters are inevitable and only their effects can be mitigated. FEMA (2010) has given a sample hazard (disaster) list. See Table 2. This is only a sample list and the possibilities of new unexpected hazards do exist. Further, grouping of hazards in such lists undermines the potential of the damage caused by a hazard due to domino/cascading effects. We have further reinforced the importance of domino/cascading effects in Section 5.2 where we have discussed the cross tabulation of Function vs. Disaster Type. As stated by FEMA (2010) "A list may give the impression that hazards or threats are independent of one another, when in fact they are often related (e.g., an earthquake might cause dam failure). Lists may group very different causes or sequences of events that require different types of responses under one category. For example, "Flood" might include dam failure, cloudbursts, or heavy rain upstream. Lists also may group a whole range of consequences under the category of a single hazard. "Terrorism," for example, could include use of conventional explosives against people or critical infrastructure; nuclear detonation; or release of lethal chemical, biological, or radiological material." 
Table 2: Sample Hazards List.

\begin{tabular}{|c|c|c|}
\hline Natural Hazards & Technological Hazards & Human-Caused Hazards \\
\hline $\begin{array}{ll}\text { - } & \text { Avalanche } \\
\text { - } & \text { Disease outbreak } \\
\text { - } & \text { Earthquake } \\
\text { - } & \text { Epidemic } \\
\text { - } & \text { Hurricane } \\
\text { - } & \text { Landslide } \\
\text { - Tornado } \\
\text { - } \\
\text { Volcanic eruption }\end{array}$ & $\begin{array}{ll}\text { - } & \text { Airplane crash } \\
\text { - } & \text { Dam/levee failure } \\
\text { - } & \text { Power failure } \\
\text { - } & \text { Radiological release } \\
\text { - } & \text { Train derailment } \\
\text { - } & \text { Urban conflagration }\end{array}$ & $\begin{array}{ll}\text { - } & \text { Civil disturbance } \\
\text { - } & \text { Cyber events } \\
\text { - } & \text { Terrorist acts } \\
\text { - } & \text { Sabotage } \\
\text { - School violence }\end{array}$ \\
\hline
\end{tabular}

Source: FEMA: Comprehensive Preparedness Guide (CPG) 101 Version 2, November 2010.

\section{Time Phases of Disasters}

We have divided the time framework into three categories: before, during and after.

Before the disaster: The functions that are generally performed before the disaster strikes include prevention, mitigation, and evacuation. The decision making process articles can also be included here.

During the disaster: The "during" phase refers to the starting time and ending time of a disaster. However, this time phase is ambiguous and difficult to define. For example, when does the during phase for a hurricanes start? Is it the time of land fall or even before that? After a hurricane forms in the ocean the activities to face this inevitable event start. The start of these activities may be a week or ten days before the land fall. Several regions start preparing depending on the probability of a strike within a given region. The forecasting of the path and the actual site of land fall are continuously monitored. Evacuations start when the hurricane is close. So does evacuation belong to the before or during the hurricane? The actual time for the hurricane to pass over a region may be only a few hours.

In case of an earthquake there is no before time phase. Perhaps someday there will be early warning since Cal Tech (and others) are trying to develop methods. See for example Earthquake.usgs.gov/research/earlywarning. An earthquake hits for 10 to 40 seconds, and it is gone. Tremors do continue after a major earthquake. Is the tremor-phase a before phase (before the tremors) 
or after (after the major hit). Evacuation activities might be performed in anticipation of the tremors often because of the fear that buildings will collapse.

In case of terrorism, say after a bomb blast, the possibilities of similar blasts, do exist. This can be coordinated terrorism anywhere in the world or close by since terrorists often use two bombs with a short interval between to maximize damage. Can preventive actions be taken during this period?

After the disaster: After a region has been hit by a disaster, the immediate activities are to provide food, medicine and shelter to the victims. Casualties have to be provided medical services. These activities continue for a short period and then the long term activities to rebuild the community start.

\subsection{Solution Domains}

Once a researcher identifies a problem scenario, he/she gets into solving the problem. The problem has to be defined, formulated, decision variables defined and constraints identified. The proposed model is to be tested and sensitivity analysis carried out. So the solution domain is the intersection between the type of data and the data analysis techniques.

Type of Data: We found that researchers have used the following three types of data to prove the validity of their models and solution techniques; Field and Archival data (F\&A), Real data and Hypothetical data. The field data are generally obtained through questionnaires, personal interview, observations or archival records. The Real data are based on studying an actual disaster. In the case of Hypothetical data the authors assumes some "reasonable" numbers to solve the model.

Data Analysis Techniques: We found that the following data analysis techniques have been used in the research papers reviewed: Bidding Models, Decision Analysis, Expert Systems, Fuzzy Systems Analysis, Game Theory, Heuristics, Mathematical programming, Network Flow Models, Queueing Theory, Simulation, Statistical Analysis, Utility Theory, and Miscellaneous. In some cases more than one technique has been used. For example, a mathematical programming model was followed by development of a heuristics algorithm. We have classified a paper based on what we considered as the major solution domain. The miscellaneous techniques include: differential equations, nonlinear differential equations, lab-based experiments, a viable system model, text data mining, structuration theory, and pattern theory. 


\section{Administrative Functions}

Table 3 lists the number of papers for each administrative function by publication year. Most of the papers are published after 2000. We have aggregated the count of papers from 1957 to 2000 because of small total number (39). Maximum number of papers (73) is in humanitarian logistics followed closely by decision making process (57). Prevention and Mitigation ranks number 3 with 49 papers followed closely by evacuation (38). There were 24 papers in casualty management. However, it may be noted that we found similarity of activities between casualty management and humanitarian logistics. Therefore, we have classified only those papers in casualty management that deal primarily with the transportation of casualties (i.e., injured people). Restoration/recovery had 18 papers. There were eight survey papers.

Table 3: Count of papers by category by year.

\begin{tabular}{|c|c|c|c|c|c|c|c|c|c|c|c|c|c|c|c|c|}
\hline Category & $\begin{array}{l}\stackrel{0}{*} \\
\text { ñ } \\
2\end{array}$ & $\underset{\mathrm{\delta}}{\overline{8}}$ & §̊ & 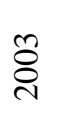 & $\underset{\sim}{\stackrel{ా}{8}}$ & 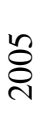 & ஜ̊ & 유 & $\stackrel{\infty}{\stackrel{\leftrightarrow}{8}}$ & ஓ्ष & $\stackrel{\circ}{\stackrel{0}{ }}$ & $\overline{\widetilde{d}}$ & $\stackrel{\sim}{\stackrel{\sim}{\sigma}}$ & $\frac{m}{\stackrel{n}{c}}$ & $\underset{\sim}{\stackrel{D}{d}}$ & 矛 \\
\hline Casualty Management & 2 & 0 & 0 & 0 & 0 & 0 & 1 & 3 & 0 & 0 & 2 & 3 & 3 & 7 & 3 & 24 \\
\hline Decision Making Process & 12 & 1 & 0 & 0 & 0 & 1 & 3 & 3 & 2 & 2 & 5 & 6 & 7 & 9 & 6 & 57 \\
\hline Evacuation & 5 & 1 & 0 & 0 & 0 & 0 & 0 & 2 & 4 & 3 & 2 & 7 & 6 & 3 & 5 & 38 \\
\hline Humanitarian Logistics & 1 & 0 & 2 & 0 & 2 & 0 & 1 & 6 & 3 & 2 & 5 & 13 & 8 & 10 & 20 & 73 \\
\hline Prevention/Mitigation & 8 & 1 & 0 & 0 & 1 & 0 & 1 & 6 & 4 & 3 & 2 & 3 & 8 & 4 & 8 & 49 \\
\hline Restoration/Recovery & 11 & 0 & 0 & 0 & 0 & 0 & 0 & 0 & 0 & 1 & 0 & 1 & 0 & 1 & 4 & 18 \\
\hline Survey & 0 & 0 & 0 & 0 & 0 & 0 & 1 & 2 & 0 & 0 & 0 & 1 & 0 & 1 & 3 & 8 \\
\hline Total & 39 & 3 & 2 & 0 & 3 & 1 & 7 & 22 & 13 & 11 & 16 & 34 & 32 & 35 & 49 & 267 \\
\hline
\end{tabular}

\subsection{Decision Making Process}

The research papers that focus on "decision making process" for managing disasters (57 papers) can be grouped into the following eight subcategories: 1. Decision support systems (DSS), 2. Multiagency decision making, 3. Information processing, 4. Systems modeling, 5. Supply chains, 6. Equity and public risk, 7. Near-miss events, and 8. Fund raising.

All references that belong to the "decision making process" category are listed in Table 4. We have used the following scheme to list the references. Each column represents one subcategory as labeled in the column heading. Each row represents an individual year with two exceptions: years 1957 to 2000 have been grouped together and similarly years 2001 to 2005 have been grouped together. In each cell, 
papers published in a specific year related to a specific subcategory are listed. The last row gives the counts of references for each subcategory for all years. Similarly, the last column gives the count of references over all subcategories for a particular year.

We have used this scheme to list references for each category in the following sections. Therefore, for the sake of avoiding duplication, we will not describe this scheme in each section again.

\section{Chronology of Development}

The total number of papers published on "decision making process" is 57 (see Table 4). Of these, 12 papers were published during 1957-2000. However, all of these 12 papers were published between 1980 and 2000. This indicates that no attention was paid in the academic literature to the "decision making process" to manage disasters before 1980. During the interval 2001-2005, one paper was published in 2001 and one in 2005; followed by 3 in 2006, 3 in 2007, 2 in 2008 and 2 in 2009. The number of papers published in 2010 is 5 with a steady increase thereafter; 6 in 2011, 7 in 2012, 9 in 2013 and 6 in 2014. Does this portend that the "decision making process" has waning interest? We should observe what happens in 2015.

From the perspective of subcategories (see Table 4) "decision support systems" (16 papers) and "multi-agency decision making" (14 papers) are on the top. The numbers of papers published in other subcategories in descending order are information processing (8), systems modeling (7), equity and public risk (4), supply chains (4), near-miss events (2), and fund raising (2). It is also evident from Table 4 that while "multi-agency decision making", "decision support systems" and "supply chains" have almost an even spread over our time horizon; "systems modeling", and "information processing" have been studied mostly during recent years. 
Table 4: References for subcategories of "decision making process" by year.

\begin{tabular}{|c|c|c|c|c|c|c|c|c|c|}
\hline \multicolumn{10}{|c|}{ Decision Making Process: List of Authors } \\
\hline $\begin{array}{l}\text { Decision } \\
\text { Making } \\
\text { Process }\end{array}$ & $\begin{array}{l}\text { Decision } \\
\text { Support } \\
\text { Systems }\end{array}$ & $\underset{\text { Risk }}{\text { Equity and Public }}$ & Fund Raising & $\begin{array}{c}\text { Information } \\
\text { Processing }\end{array}$ & $\begin{array}{c}\text { Multi-agency Decision } \\
\text { Making }\end{array}$ & $\begin{array}{l}\text { Near-miss } \\
\text { Events }\end{array}$ & $\begin{array}{l}\text { Supply } \\
\text { Chains }\end{array}$ & $\begin{array}{l}\text { Systems } \\
\text { Modeling }\end{array}$ & Total \\
\hline $\begin{array}{l}1957- \\
2000\end{array}$ & \begin{tabular}{|c|} 
Kananen et al. \\
(1990), Dai et \\
al. (1994), \\
Fogli and \\
Guida (1995), \\
Mak et al. \\
(1999), \\
Papamichail \\
and French \\
(1999)
\end{tabular} & $\begin{array}{c} \\
\text { Keeney (1980), } \\
\text { Hammerton et al. } \\
\text { (1982), Fishburn } \\
\text { (1984), Keeney } \\
\text { and Winkler (1985) } \\
\end{array}$ & & & $\begin{array}{c}\text { Belardo et al. (1983), } \\
\text { Gregory and Midgley } \\
(2000)\end{array}$ & & & Arbel (1980) & 12 \\
\hline $\begin{array}{l}2001 \text { to } \\
2005\end{array}$ & $\begin{array}{l}\text { Papamichail } \\
\text { and French } \\
(2005)\end{array}$ & & & $\begin{array}{l}\text { Bui and } \\
\text { Sankaran } \\
(2001)\end{array}$ & & & & & 2 \\
\hline 2006 & $\begin{array}{l}\text { Lee et al. } \\
\text { (2006) }\end{array}$ & & & & $\begin{array}{l}\text { Van Wassenhove } \\
\text { (2006) }\end{array}$ & & $\begin{array}{l}\text { Oloruntoba } \\
\text { and Gray } \\
(2006)\end{array}$ & & 3 \\
\hline 2007 & $\begin{array}{l}\text { Mendonça } \\
(2007)\end{array}$ & & & & Min et al. (2007) & & & $\begin{array}{l}\text { Kim et al. } \\
(2007)\end{array}$ & 3 \\
\hline 2008 & $\begin{array}{l}\text { Yoon et al. } \\
(2008)\end{array}$ & & & & & $\begin{array}{c}\text { Dillon and } \\
\text { Tinsley (2008) }\end{array}$ & & & 2 \\
\hline 2009 & & & & & $\begin{array}{c}\text { van Baalena and van } \\
\text { Fenema (2009) }\end{array}$ & & $\begin{array}{l}\text { Maon et al. } \\
(2009)\end{array}$ & & 2 \\
\hline 2010 & & & & & $\begin{array}{l}\text { Balcik et al. (2010), } \\
\text { Tatham and Kovács } \\
\text { (2010), Oloruntoba } \\
(2010) \text {, Egan (2010) }\end{array}$ & & $\begin{array}{l}\text { Gatignon et al. } \\
\quad(2010)\end{array}$ & & 5 \\
\hline 2011 & $\begin{array}{l}\text { Moskowitz et } \\
\text { al. (2011) }\end{array}$ & & & $\begin{array}{l}\text { Lu and Yang } \\
\text { (2011), Lee et } \\
\text { al. (2011) }\end{array}$ & Yu and Lai (2011) & & & $\begin{array}{c}\text { Charles and } \\
\text { Lauras (2011) }\end{array}$ & 5 \\
\hline 2012 & $\begin{array}{l}\text { Shen et al. } \\
\text { (2012) }\end{array}$ & & & $\begin{array}{c}\text { Eiselt and } \\
\text { Marianov } \\
(2012)\end{array}$ & $\begin{array}{l}\text { Rodon et al. (2012), } \\
\text { Heaslip et al. (2012) }\end{array}$ & $\begin{array}{l}\text { Tinsley et al. } \\
\quad(2012)\end{array}$ & $\begin{array}{l}\text { Day et al. } \\
\text { (2012) }\end{array}$ & \begin{tabular}{|} 
Holguín-Veras \\
et al. (2012)
\end{tabular} & 7 \\
\hline 2013 & $\begin{array}{c}\text { Fogli and } \\
\text { Guida (2013), } \\
\text { Haghighi et al. } \\
\text { (2013), } \\
\text { Amailef and Lu } \\
(2013) \text {, Araz et } \\
\text { al. (2013) }\end{array}$ & & & $\begin{array}{l}\text { Li et al. } \\
\text { (2013), Preece } \\
\text { et al. (2013) }\end{array}$ & Edrissi et al. (2013) & & & \begin{tabular}{|} 
Holguín-Veras \\
et al. (2013), \\
Ishizaka and \\
Labib (2013)
\end{tabular} & 9 \\
\hline 2014 & $\begin{array}{l}\text { Rakes et al. } \\
\quad(2014)\end{array}$ & & $\begin{array}{c}\text { Bhattacharya } \\
\text { et al. (2014), } \\
\text { Toyasaki and } \\
\text { Wakolbinger } \\
(2014)\end{array}$ & $\begin{array}{c}\text { Li et al. } \\
\text { (2014), Altay } \\
\text { and Pal (2014) }\end{array}$ & Ergun et al. (2014) & & & $\begin{array}{l}\text { Liu et al. } \\
\text { (2014) }\end{array}$ & 7 \\
\hline Total & 16 & 4 & 2 & 8 & 14 & 2 & 4 & 7 & 57 \\
\hline
\end{tabular}

In the field of "decision making process", areas such as "Near-miss events", "Fund raising", "Equity and public risk", "Supply chains", "Systems modeling" and "Information processing" do not seem to have been covered sufficiently. These functions are ripe for more research.

\subsection{Prevention/ Mitigation}

Prevention and mitigation activities can reduce the impact of disasters. Prevention activities aim at avoiding the possibility of getting hit by a disaster. Paying attention to warning signals and taking 
preventive measures can avoid catastrophes. This is particularly important to avoid industrial accidents and terrorist activities. When disasters are inevitable, steps are taken to reduce their impacts through mitigation activities. The examples include building levees in flood prone zones and establishing buildings codes to strengthen buildings, bridges and other infrastructure.

The studies related to prevention/ mitigation (49 papers) can be grouped into the following six subcategories: 1. Attacker/ Defenders strategies, 2. Infrastructure development, 3. Resilience, 4. Resource allocation, 5. Risk management, and 6. Surveillance.

\section{Chronology of Development}

Table 5 lists the publication references for each category by year. Eight papers were published during the interval, 1957-2000 with the earliest one in 1975 on risk management. In most of the years the number of papers ranged from one to four with the following exceptions. There were six papers in 2007 and eight papers each in 2012 and 2014. From the subcategory perspective, risk management is the most studied topic with 19 papers followed by resource allocation (8), attacker/defender strategies (7), resilience (6) infrastructure development (5), and surveillance (4). Further, "Infrastructure development" has been studied till the end of 2010 and "Resource allocation" has been studied between 2007 and 2014. The papers on "Risk management" are distributed over most of the years.

Prevention/mitigation has 49 papers as compared to humanitarian logistics that has 73 papers. Sound prevention/mitigation strategies can possibly reduce efforts and resources spent on the humanitarian logistics activities. It is the logical way to use resources, namely, don't spend all the funds fighting fires, instead, spend on learning how to prevent fires. Also prevention/mitigation strategies have strong linkages with developments in engineering and technology. Developments in all these fields have to be integrated to assess preparedness for disasters. The researchers in humanitarian logistics can try to address the question: could anything have been done to prevent this disaster or mitigate its severity before it occurred? 
Table 5: References for subcategories of "prevention/ mitigation" by year.

\begin{tabular}{|c|c|c|c|c|c|c|c|}
\hline \multicolumn{8}{|c|}{ Prevention/Mitigation: List of Authors } \\
\hline $\begin{array}{c}\text { Prevention/ } \\
\text { Mitigation } \\
\text { Subcategories }\end{array}$ & $\begin{array}{l}\text { Attacker/ } \\
\text { Defender } \\
\text { Strategies }\end{array}$ & $\begin{array}{l}\text { Infrastructure } \\
\text { Development }\end{array}$ & Surveillance & Resilience & $\begin{array}{l}\text { Resource } \\
\text { Allocation }\end{array}$ & Risk Management & Total \\
\hline $1957-2000$ & & $\begin{array}{l}\text { Tamura et al. } \\
\text { (2000) }\end{array}$ & $\begin{array}{c}\text { Current and } \\
\text { O'Kelly (1992) }\end{array}$ & & & $\begin{array}{c}\text { Glickman and } \\
\text { Rosenfield (1984), } \\
\text { Rivas and Rudd } \\
\text { (1975), Sampson and } \\
\text { Smith (1982), } \\
\text { Ermoliev et al. (2000), } \\
\text { Widberg (1989), } \\
\text { Haastrup (1994) }\end{array}$ & 8 \\
\hline 2001 to 2005 & & & & & & $\begin{array}{c}\text { Riddington et al. } \\
\text { (2004), Wolf (2001) }\end{array}$ & 2 \\
\hline 2006 & & & $\begin{array}{l}\text { Lazar Babu and } \\
\text { Lin (2006) }\end{array}$ & & & & 1 \\
\hline 2007 & \begin{tabular}{|c|} 
Zhuang and \\
Bier (2007), \\
Berman and \\
Gavious (2007) \\
\end{tabular} & $\begin{array}{l}\text { Dodo et al. } \\
\text { (2007) }\end{array}$ & $\begin{array}{l}\text { Berndt et al. } \\
\quad(2007)\end{array}$ & & $\begin{array}{l}\text { Pinker } \\
(2007)\end{array}$ & Larson (2007) & 6 \\
\hline 2008 & & $\begin{array}{c}\text { Bana e Costa et } \\
\text { al. (2008) }\end{array}$ & & & $\begin{array}{c}\text { Scaparra } \\
\text { and Church } \\
\text { (2008) }\end{array}$ & $\begin{array}{l}\text { Snediker et al. (2008), } \\
\text { Das et al. (2008) }\end{array}$ & 4 \\
\hline 2009 & & $\begin{array}{l}\text { Matisziw and } \\
\text { Murray (2009) }\end{array}$ & & & $\begin{array}{l}\text { Golany et } \\
\text { al. (2009) }\end{array}$ & $\begin{array}{l}\text { Nigmatulina and } \\
\text { Larson (2009) }\end{array}$ & 3 \\
\hline 2010 & & $\begin{array}{l}\text { Peeta et al. } \\
\text { (2010) }\end{array}$ & & & $\begin{array}{c}\text { Arora et al. } \\
(2010)\end{array}$ & & 2 \\
\hline 2011 & & & & $\begin{array}{l}\text { Zobel } \\
(2011)\end{array}$ & $\begin{array}{l}\text { Liberatore } \\
\text { et al. (2011) }\end{array}$ & $\begin{array}{l}\text { Rodríguez et al. } \\
\text { (2011) }\end{array}$ & 3 \\
\hline 2012 & $\begin{array}{c}\text { Hausken and } \\
\text { Zhuang (2012) }\end{array}$ & & $\begin{array}{l}\text { Majeske and } \\
\text { Lauer (2012) }\end{array}$ & $\begin{array}{l}\text { Miller- } \\
\text { Hooks et al. } \\
\text { (2012), } \\
\text { Losada et } \\
\text { al. (2012) }\end{array}$ & $\begin{array}{l}\text { Berman et } \\
\text { al. (2012) }\end{array}$ & $\begin{array}{l}\text { Hiete et al. (2012), } \\
\text { Rodríguez et al. } \\
\text { (2012), Peng (2012) }\end{array}$ & 8 \\
\hline 2013 & $\begin{array}{l}\text { Roy and Paul } \\
\text { (2013), Shan } \\
\text { and Zhuang } \\
\text { (2013) }\end{array}$ & & & & $\begin{array}{c}\text { Hausken } \\
\text { and Zhuang } \\
\text { (2013) }\end{array}$ & $\begin{array}{c}\text { Kumar and Havey } \\
\text { (2013) }\end{array}$ & 4 \\
\hline 2014 & $\begin{array}{c}\text { Baykal-Gürsoy } \\
\text { et al. (2014), } \\
\text { Bagchi and Paul } \\
\text { (2014) }\end{array}$ & & & $\begin{array}{l}\text { Zobel and } \\
\text { Khansa } \\
(2014), \\
\text { Zeng and } \\
\text { Xiao } \\
\text { (2014), } \\
\text { Scholten et } \\
\text { al. (2014) }\end{array}$ & & $\begin{array}{l}\text { Qiu et al. (2014), } \\
\text { Grechuk and } \\
\text { Zabarankin (2014) }\end{array}$ & 8 \\
\hline Total & 7 & 5 & 4 & 6 & 7 & 19 & 48 \\
\hline
\end{tabular}




\subsection{Evacuation}

Evacuation is a strategic decision to reduce the impact of the severity of a disaster on human lives. Evacuation planning involves the choice of destination where people will be moved (locations of shelters), how far in advance warnings for evacuation will be issued, selection of the evacuation route, scheduling of evacuees (how far in advance people have to be moved, which area are to evacuated first, which group of people are moved first). Evacuation decisions are impacted by people's personal preferences - some people do not want to evacuate; whether people use their private vehicles or a public transport is used. In case of using a public transport there is an added complexity of picking up evacuees. Problem of evacuating a facility (building or a ship) is different from evacuating a general area. In this section, we include those studies that focus on evacuation activities before the disaster strikes. The section on casualty management will include studies to rescue the injured people.

The available studies (38 papers) in this section have been divided into the following four categories: 1. Shelter Location, 2. Implementation Issues, 3. Facilities (buildings, ships, plants) Evacuation, and 4. Routing and Scheduling.

\section{Chronology of Development}

Table 6 lists the publication references for each category by year. Only five papers (one in 1987, two in 1991, one in 1996 and one in 2000) were published during the early years 1957 to 2000 followed by one paper in 2001 during the interval 2001-2005 and no publication in 2006. Two papers were published in 2007. The number of publications then jumped to four in 2008 and then declined to three in 2009 and to two in 2010. There was a big jump to seven papers in 2011 but again the numbers declined to six in 2012 and to three in 2013. The number of papers again increased to 5 in 2014. There seems to be a steady decline after 2011. The most studied subcategory is routing and scheduling with 20 papers followed by facility evacuation (9), implementation issues (6) and shelter location (3).

Implementation issues are very important for effective evacuation. There are only six out of 38 papers on implementation. Evacuation is a mitigation strategy. Routing and Scheduling are tactical and lend themselves to OR modeling whereas Implementation Issues are strategic concerns and difficult to model using quantitative techniques. This probably accounts for the fact that the former has more than three times the number of papers that the latter has. Good faculty guidance can help to address this imbalance. Overall, this area needs more attention. 
Table 6: References for subcategories of "evacuation" by Year.

\begin{tabular}{|c|c|c|c|c|c|}
\hline \multicolumn{6}{|c|}{ Evacuation: List of Authors } \\
\hline $\begin{array}{c}\text { Evacuation } \\
\text { Subcategories }\end{array}$ & $\begin{array}{c}\text { Facilities } \\
\text { Evacuation }\end{array}$ & $\begin{array}{c}\text { Implementation } \\
\text { Issues }\end{array}$ & $\begin{array}{c}\text { Routing and } \\
\text { Scheduling }\end{array}$ & Shelter Location & Total \\
\hline $1957-2000$ & $\begin{array}{c}\text { Hamacher and } \\
\text { Tufekci (1987), } \\
\text { Smith (1991) }\end{array}$ & $\begin{array}{c}\text { Pidd et al. (1996), } \\
\text { de Silva and Eglese } \\
\text { (2000) }\end{array}$ & & $\begin{array}{c}\text { Sherali and Carter } \\
\text { (1991) }\end{array}$ & 5 \\
\hline 2001 to 2005 & Mould (2001) & & & & 1 \\
\hline 2006 & & & & & 0 \\
\hline 2007 & & & $\begin{array}{c}\text { Chiu et al. (2007), } \\
\text { Chiu and Zheng } \\
\text { (2007) }\end{array}$ & & 2 \\
\hline 2008 & $\begin{array}{l}\text { Chen and Miller- } \\
\text { Hooks (2008), } \\
\text { Pérez-Villalonga et } \\
\text { al. (2008) }\end{array}$ & & $\begin{array}{l}\text { Regnier (2008), } \\
\text { Chen and Zhan } \\
\quad(2008)\end{array}$ & & 4 \\
\hline 2009 & $\begin{array}{l}\text { Opasanon and } \\
\text { Miller-Hooks } \\
\quad(2009)\end{array}$ & & $\begin{array}{c}\text { Stepanov and Smith } \\
\text { (2009), } \\
\text { Saadatseresht et al. } \\
(2009)\end{array}$ & & 3 \\
\hline 2010 & & & $\begin{array}{c}\text { Xie et al. (2010), } \\
\text { Ng and Waller } \\
(2010)\end{array}$ & & 2 \\
\hline 2011 & Bish et al. (2011) & $\begin{array}{c}\text { Hasan and Ukkusuri } \\
\text { (2011) }\end{array}$ & $\begin{array}{c}\text { Kimms and } \\
\text { Maassen (2011), } \\
\text { Bish (2011), Ben- } \\
\text { Tal et al. (2011), } \\
\text { Huibregtse et al. } \\
\text { (2011) }\end{array}$ & Li et al. (2011) & 7 \\
\hline 2012 & & $\begin{array}{l}\text { Uchida (2012), } \\
\text { Nagarajan et al. } \\
\text { (2012) }\end{array}$ & $\begin{array}{l}\text { Rungta et al. (2012), } \\
\text { Duanmu et al. } \\
(2012), \\
\text { Bretschneider and } \\
\text { Kimms (2012) } \\
\end{array}$ & Li et al. (2012) & 6 \\
\hline 2013 & An et al. (2013) & & $\begin{array}{c}\text { Bish and Sherali } \\
\text { (2013), Hamacher et } \\
\text { al. (2013) }\end{array}$ & & 3 \\
\hline 2014 & $\begin{array}{l}\text { Abdelghany et al. } \\
\text { (2014) }\end{array}$ & Liu et al. (2014) & $\begin{array}{l}\text { Bish Et al. (2014), } \\
\text { Tuydes-Yaman and } \\
\text { Ziliaskopoulos } \\
\text { (2014), Goerigk and } \\
\text { Grün (2014) } \\
\end{array}$ & & 5 \\
\hline Total & 9 & 6 & 20 & 3 & 38 \\
\hline
\end{tabular}

\subsection{Humanitarian logistics}

After a disaster strikes, the relief supplies and medical supplies are to be delivered to the victims in the affected areas. The transportation of victims and casualties is also very important but this has been discussed in the section on casualty management. The planning and execution of operational activities 
is the subject matter of humanitarian logistics. The studies related to humanitarian logistics (73 papers) can be categorized into the following seven subcategories: 1. Allocation of Supplies, 2. Distribution of Supplies, 3. Location of Distribution Centers, 4. Procurement, 5. Location-Allocation. 6. LocationDistribution, and 7. Location-Allocation-Distribution.

\section{Chronology of Development}

Table 7 lists the publication references for each sub-category by year. There were a total of 73 papers of which 51 papers have been published in the last four years - 2011 (13), 2012 (8), 2013 (10) and 2014 (20). There was only one paper in 1992 during the period 1957-2000. The count in other years is 2001-2005 (4), 2006 (1), 2007 (6), 2008 (3), 2009 (2) and 2010 (5).

Distribution of supplies with 28 papers had the major research thrust followed by location of distribution centers (12). Allocation of supplies and procurement had nine papers each followed by location-allocation (7), location-allocation-distribution (5) and location-distribution (3).

There was a special issue of POM dedicated to Humanitarian Operations and Crisis Management in June of 2014 (see Starr and Wassenhove, 2014). The term "operations" is totally substitutable for "logistics" in this context.

While there has been considerable number of research papers for "Distribution of supplies", "Location of distribution centers" and "Allocation of supplies", it seems that other issues especially hybrid issues have not been covered enough which can indicate a potential gap for further studies. See, for example, Vanajakumari et al., (2016). 
Table 7: References for subcategories of "humanitarian logistics" by year.

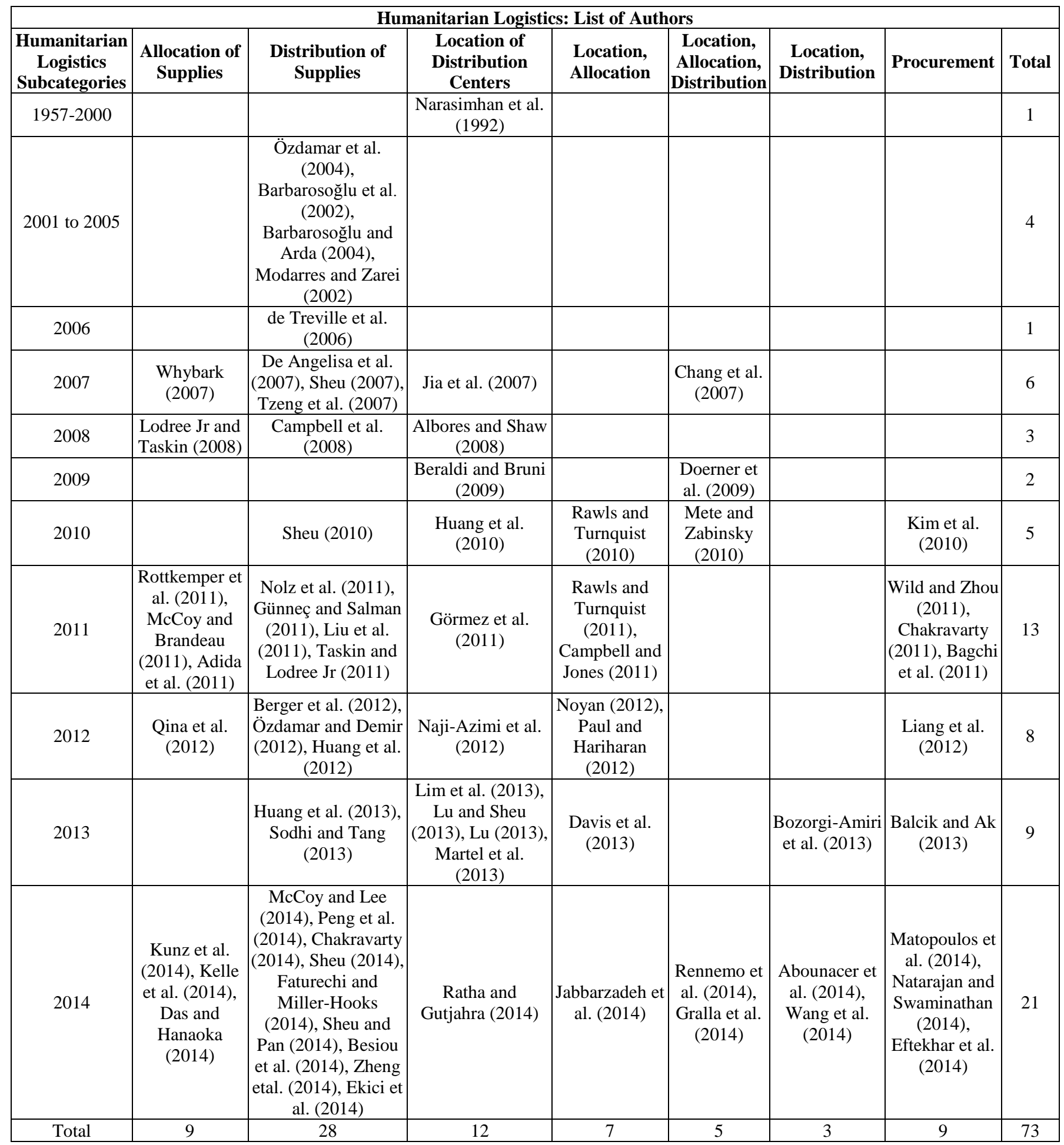




\subsection{Casualty Management}

Once a disaster strikes, locating casualties, moving casualties to safer places including hospitals, providing medical facilities on the disaster site and distributing relief supplies (food and shelter) to the affected areas are the important activities. These activities are critical since right and effective preplanning of them can save tremendous number of lives. Information technology and social media play an important role in this phase of disaster management. However, due to our focus on POM journals in this survey there was an absence of IT related papers. We can categorize studies related to casualty management (24 papers) into the following four subcategories: 1. Hospital Capacity, 2. Resource Allocation, 3. Supplies Distribution and Rescue Operations, and 4. Triage.

\section{Chronology of Development}

Table 8 lists the publication references for each sub-category by year. The total number of papers published on "casualty management" is 24 . The counts of the number of publications in various years are: 1957-2000 (2), 2006 (1), 2007 (3), 2010 (2), 2011 (3), 2012 (3), 2013 (6) and 2014 (4). The earliest two studies were on triage in 1976 and on resource allocation in 1977. There were no publications in 2008 and 2009.

From the perspectives of subcategories, "supplies distribution and rescue operations" has the highest number of papers (10) followed by resource allocation (6), triage (6) and hospital capacity (2). Adequate "Hospital capacity" is important during a disaster but there is a paucity of research on this topic. 
Table 8: References for subcategories of "casualty management" by year.

\begin{tabular}{|c|c|c|c|c|c|}
\hline \multicolumn{6}{|c|}{ Casualty Management: List of Authors } \\
\hline $\begin{array}{c}\text { Casualty } \\
\text { Management }\end{array}$ & $\begin{array}{l}\text { Hospital } \\
\text { Capacity }\end{array}$ & $\begin{array}{c}\text { Resource } \\
\text { Allocation }\end{array}$ & $\begin{array}{l}\text { Supplies Distribution } \\
\text { and Rescue Operations }\end{array}$ & Triage & Total \\
\hline $1957-2000$ & & Cook (1977) & & Hutchinson (1976) & 2 \\
\hline 2001 to 2005 & & & & & 0 \\
\hline 2006 & & & Drezner et al. (2006) & & 1 \\
\hline 2007 & & $\begin{array}{l}\text { Gong and Batta } \\
\text { (2007) }\end{array}$ & $\begin{array}{l}\text { Yi and Kumar (2007), } \\
\text { Yi and Özdamar (2007) }\end{array}$ & & 3 \\
\hline 2008 & & & & & 0 \\
\hline 2009 & & & & & 0 \\
\hline 2010 & $\begin{array}{l}\text { Valdmanis } \\
\text { (2010) }\end{array}$ & & $\begin{array}{l}\text { Salmeron and Apte } \\
\text { (2010) }\end{array}$ & & 2 \\
\hline 2011 & & $\begin{array}{l}\text { Valdmanis et } \\
\text { al.(2011) }\end{array}$ & Özdamar (2011) & Cotta (2011) & 3 \\
\hline 2012 & & $\begin{array}{c}\text { Rachaniotis et al. } \\
(2012)\end{array}$ & $\begin{array}{c}\text { Chen and Miller-Hooks } \\
(2012)\end{array}$ & Jacobson et al. (2012) & 3 \\
\hline 2013 & Chan et al (2013) & $\begin{array}{l}\text { Kilic (2013), Sun } \\
\text { et al. (2013) }\end{array}$ & $\begin{array}{c}\text { Najafi et al. (2013), } \\
\text { Wex et al. (2013), } \\
\text { Wilson et al. (2013) }\end{array}$ & Mills et al. (2013) & 7 \\
\hline 2014 & & & Najafi et al. (2014) & $\begin{array}{l}\text { Xiang and Zhuang } \\
\text { (2014), Dean and } \\
\text { Nair (2014) }\end{array}$ & 3 \\
\hline Total & 2 & 6 & 10 & 6 & 24 \\
\hline
\end{tabular}

\subsection{Restoration/Recovery}

The major goal in the restoration/recovery phase is to rebuild and restore houses, facilities and infrastructure. The studies related to restoration/recovery can be grouped in the following four categories: 1. Damage Assessment, 2. Debris Clean-up, 3. Oil Spills, and 4. Road Repairs.

\section{Chronology of Development}

Table 9 lists the publication references for each sub-category by year. A total of 18 studies were found on restoration/recovery. The earliest study was on damage assessment in the year 1958. After that there is only one other study on damage assessment in 2014. Eleven out of 18 studies focused on oil spills; ten of these studies were done between 1957 and 2000 and one was done in 2014. Four studies were found on road repairs and one on debris cleanup. 
Table 9: References for subcategories of "recovery/restoration" by year.

\begin{tabular}{|c|c|c|c|c|c|}
\hline \multicolumn{6}{|c|}{ Restoration/Recovery: List of Authors } \\
\hline $\begin{array}{c}\text { Restoration/ } \\
\text { Recovery } \\
\text { Subcategories }\end{array}$ & $\begin{array}{c}\text { Damage } \\
\text { Assessment }\end{array}$ & Debris Cleanup & Oil Spills & Road Repairs & Total \\
\hline $1957-2000$ & Ramsey Jr. (1958) & & $\begin{array}{c}\text { Belardo et al. (1984), } \\
\text { Wilhelm and Srinivasa } \\
\text { (1996), Wilhelm and } \\
\text { Srinivasa (1997), Psaraftis } \\
\text { and Ziogas (1985), Psaraftis et } \\
\text { al. (1986), Iakovou et al. } \\
\text { (1994), Jenkins (2000), } \\
\text { Iakovou et al. (1997), } \\
\text { Srinivasa and Wilhelm } \\
\text { (1997), Gottinger (1998) }\end{array}$ & & 11 \\
\hline 2001 to 2005 & & & & & 0 \\
\hline 2006 & & & & & 0 \\
\hline 2007 & & & & & 0 \\
\hline 2008 & & & & & 0 \\
\hline 2009 & & & & $\begin{array}{c}\text { Yan and Shih } \\
\text { (2009) }\end{array}$ & 1 \\
\hline 2010 & & & & & 0 \\
\hline 2011 & & & & $\begin{array}{c}\text { Duque and } \\
\text { Sörensen (2011) } \\
\end{array}$ & 1 \\
\hline 2012 & & & & & 0 \\
\hline 2013 & & $\begin{array}{l}\text { Hu and Sheu } \\
\text { (2013) }\end{array}$ & & & 1 \\
\hline 2014 & Kou et al. (2014) & & Passos et al. (2014) & \begin{tabular}{|c|} 
Aksu and \\
Özdamar (2014), \\
Liberatore et al. \\
$(2014)$ \\
\end{tabular} & 4 \\
\hline Total & 2 & 1 & 11 & 4 & 18 \\
\hline
\end{tabular}

Recovery/restoration has been an understudied area with only 18 research papers. The research focus is primarily on oil spills. The researchers while working on recovery/restoration issues may also like to analyze whether the disaster situation could have been prevented (and/or alleviated) and if so how?

\section{Cross Tabulation}

For the purpose of cross tabulation, we selected the papers published in the last four years (2011 to 2014). The research in disaster management picked up in the year 2011 (see Table 1). The last four years are a good representation of research trends. We found 150 papers during these four years of which there are 4 survey papers. So the cross tabulations are done for 146 papers. In some tables the total number of papers is more than 146 because some papers are double counted. For example, if a 
paper discusses hurricanes as well as floods, then, this paper is counted under the hurricane category as well as under the flood category. Based on the five attributes discussed above we have created the following seven cross tabulations: 1. Function vs. Time (Table 10), 2. Function vs. Type of Disaster (Table 11), 3. Function vs. Data Type (Table 12), 4. Function vs. Data Analysis Techniques (Table 13). 5. Data Type vs. Data Analysis Techniques (Table 14), 6. Disaster Type vs. Data Analysis Techniques (Table 15), and 7. Data Type vs. Disaster Type (Table 16). Findings based on these tables are discussed below in the following seven subsections.

\subsection{Function vs. Time}

Table 10: Function vs. Time.

\begin{tabular}{|c|c|c|c|c|}
\hline Function vs. Time & $\begin{array}{l}0 \\
\stackrel{0}{0} \\
\infty \\
\infty\end{array}$ & $\begin{array}{l}0.00 \\
\end{array}$ & 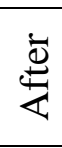 & $\stackrel{\vec{\Xi}}{0}$ \\
\hline Casualty Management & 1 & 4 & 13 & 18 \\
\hline Decision Making Process & 9 & 8 & 19 & 36 \\
\hline Evacuation & 20 & 1 & 3 & 24 \\
\hline Humanitarian Logistics & 22 & 8 & 36 & 66 \\
\hline Prevention/Mitigation & 18 & 1 & 8 & 27 \\
\hline Restoration/Recovery & 1 & 0 & 6 & 7 \\
\hline Total & 71 & 22 & 85 & 178 \\
\hline
\end{tabular}

The review of data in Table 10 shows that the most studied area is "after" the disaster ( 85 papers) followed by "before" the disaster (71 papers). That makes almost $50 \%$ of the papers dealing with the aftermath. "During" the disaster accounts for only 22 papers (about 12\%); perhaps because no actions can be taken during the disaster phase - it is only wait and see. At the same time, some essential services may be active during this period like police and fire etc. Can we find potential research problems in the chaos of during phase? This is an area ripe for research.

One of the most difficult aspects of the "During" phase is that information is often incorrect or non-existent. "Before" permits speculation and conjecture and "After" can be based on some solid observations. What should be evident is that decisions made in the "During" phase are probably quite devastating when they are wrong because corrective actions are almost impossible to achieve. 
In Table 10, there are eight instances of attention to the Decision Making Process during the disaster. That is $22 \%$. "During" is when decision making under uncertainty prevails and it seems clear that researchers want to avoid dealing with problems of uncertainty. Consequently, we recommend investments in information to alleviate these problems. In fact, it is quite possible that social media at work during a disaster should be harnessed, regulated, disciplined and controlled to achieve more successful decisions in the "during" phase.

The cross section between humanitarian logistics and "after the disaster" has drawn maximum attention of the researchers (36 papers), followed by humanitarian logistics and the "before" function (22 papers). As an example of the latter situation, see the forthcoming paper in POM on prepositioning of critical supplies for predictable disasters (Vanajakumari et al., 2016). Such papers might well be considered as efforts to mitigate the severity of potential disasters. Thus, we readily see the overlap between the three major functions in the "before" category, namely:-evacuation, humanitarian logistics and prevention/mitigation. The decision making process has received the most attention in the "after" disaster category.

\subsection{Function vs. Disaster Type}

Table 11: Function vs. Disaster Type.

\begin{tabular}{|c|c|c|c|c|c|c|c|c|c|c|}
\hline Function vs. Disaster Type & $\frac{\mathscr{0}}{\frac{0}{0}}$ & 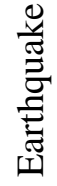 & 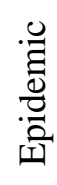 & $\frac{\bar{O}}{\frac{0}{I I}}$ & 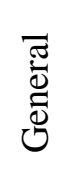 & 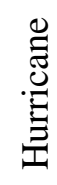 & 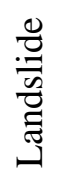 & 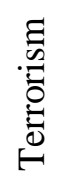 & 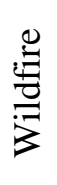 & 吾 \\
\hline Casualty Management & 2 & 5 & 2 & 1 & 7 & 0 & 0 & 0 & 0 & 17 \\
\hline Decision Making Process & 2 & 5 & 4 & 0 & 13 & 2 & 0 & 2 & 0 & 28 \\
\hline Evacuation & 1 & 1 & 0 & 1 & 9 & 8 & 1 & 0 & 1 & 22 \\
\hline Humanitarian Logistics & 0 & 14 & 1 & 3 & 26 & 9 & 0 & 1 & 0 & 54 \\
\hline Prevention/Mitigation & 2 & 5 & 0 & 2 & 6 & 2 & 0 & 9 & 0 & 26 \\
\hline Restoration/Recovery & 1 & 3 & 0 & 0 & 2 & 1 & 0 & 0 & 0 & 7 \\
\hline Total & 8 & 33 & 7 & 7 & 63 & 22 & 1 & 12 & 1 & 154 \\
\hline
\end{tabular}

The review of data in Table 11 shows that earthquakes (33 papers) and hurricanes (22 papers) are the two most studied disasters followed by terrorism (12 papers), accidents ( 8 papers) and floods (6 
papers). The eight papers under accidents include HAZMAT (4 papers), air plane crash (2 papers), nuclear power plant (1 paper) and wildfire disaster (1). In spite of the evidence that accidents are the most preventable of all the disasters, the OM community seems to have ignored the obvious. Is this because of the scale of an accident as compared to that of a geographical disaster?

This survey reveals serious gaps in what needs to be done. Helping injured people is essential and commendable. Preventing people from being injured may not seem to be as dramatic and it may be far less appealing for donors, philanthropists, and do-gooders, but it is quintessential. Prevention, mitigation and alleviation set the standard to be met and surpassed. The logic of disaster avoidance takes precedence over the logistics of humanitarian aid.

The "General" category includes those papers that do not specifically say that the considered disaster is either natural or manmade. These papers present a model or methodology, that the authors claim, may be applicable to any disaster regardless of its type. The general category, which is the largest category (63 papers), includes humanitarian logistics (26 papers) followed by decision making process (13 papers), evacuation (9 papers), casualty management ( 7 papers), prevention/mitigation (6 papers) and restoration/recovery (2). It is surprising that such a large number of papers are found in general category. What is the reason? In our opinion the authors of such papers have to qualify their claims since the nature of disasters is different from each other.

Some important disasters that have not been studied include: tornadoes, winter snow storms that shut down entire regions, volcanoes, tsunamis and power failures that bring entire cities to a halt. New York City has experienced three major instances: first was November 9, 1965; then again 12 years later on July $13^{\text {th }} 1977$; and then, 26 years later on August 14, 2003. The largest blackout in history (thus far) occurred in India on July $30^{\text {th }}$ and $31^{\text {st }}, 2012$. See the following link to know more about major power outages around the world: https://en.wikipedia.org/wiki/List_of_major_power_outages.

Domino/cascading effects have not been studied. The importance of domino/cascading effects was pointed out by FEMA (2010) as discussed earlier in section 3.1.2 (Types of Disasters).

Some other observations include the following.

- There were far fewer accident papers than earthquakes (8 vs. 22). We may conjecture that this may be because the scale of most accidents is much smaller than the scale of large earthquakes. Media coverage is significantly different. Small earthquakes are not covered. Certain locales in California have hundreds of small earthquakes daily for weeks at a time.) 
- Prevention and Mitigation has approximately $16 \%$ of all work. In the logic of economics, this would be a very low number of papers indicating minimum research interest in stopping disasters. (Perhaps such papers go into professional journals such as healthcare and engineering publications. For examples, there were many papers published in technical journals about how to prevent bridges suffering the fate of the Tacoma bridge in 1940).

- Prevention is the main focus under terrorism. It accounts for $75 \%$ of all terrorism papers. That seems as it should be.

- Preventing accidents is not generating the kind of interest it should create. POM leaders should provide some guidance to incentivize research along prevention and mitigation lines.

- The General Category can inhibit worthwhile research. See Recommendation 2 in Section 7 for an example of a generalization that violates taxonomical common sense. Disasters are unique and particular. Generalizations are less likely to be accurate in any particular situation. The field is not ready for such work. When it is ready, we should be able to say here is what is generically similar for all situations and here is what are the differences for earthquakes, hurricanes, floods, etc.

- The evacuation functions are very specific to type of disasters such as evacuation which is removing from harm's way as compared to bringing needed supplies to someone. The fact is that evacuation (exportation from a center) is an entirely different function from supplies moving toward a center (importation).

\subsection{Function vs. Data Type}

Table 12: Function vs. Data Type.

\begin{tabular}{|c|c|c|c|c|c|}
\hline Function vs. Data Type & $\underset{\$}{\$}$ & 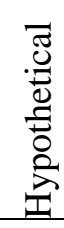 & $\begin{array}{l}\widetilde{J} \\
\stackrel{4}{4}\end{array}$ & 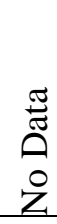 & 吾 \\
\hline Casualty Management & 0 & 10 & 7 & 0 & 17 \\
\hline Decision Making Process & 10 & 7 & 9 & 2 & 28 \\
\hline Evacuation & 0 & 12 & 9 & 0 & 21 \\
\hline Humanitarian Logistics & 2 & 27 & 21 & 1 & 51 \\
\hline Prevention/Mitigation & 4 & 9 & 6 & 4 & 23 \\
\hline Restoration/Recovery & 0 & 1 & 5 & 0 & 6 \\
\hline Total & 16 & 66 & 57 & 7 & 146 \\
\hline
\end{tabular}


The review of data in Table 12 shows that most papers have either used Hypothetical data (66) or Real data (57). In Hypothetical data the authors give an example to show calculations for their proposed model and carry out sensitivity analysis or build scenarios. The Real data are collected through a study of real disaster events.

We found seven papers where no data were used. The authors simply proposed the model. Hypothetical data would be meaningless unless modeled on some assumptions about reality. Therefore, wherever data is used it must have some observations as foundation. Therefore, Hypothetical data should always be questioned for accuracy of modeling. Some additional observations include the following.

- F\&A data (16) has been used mainly in the Decision Making Process. In fact, Real data (9) and F\&A data (10) are about equal. At this moment, it really behooves us to distinguish between F\&A data and Real data.

- Surprisingly, Casualty Management has zero (0) data derived from F\&A.

- The conclusions and recommendations are likely to be stronger if they are based on Real data properly collected as opposed to those situations where No Data is collected? Good ideas are valued whether or not the supporting data is provided. However, there is a scientific basis for testing hypotheses with Real data that should not be dismissed. Each situation must be judged on its own merits. The demand for data could create a philosophy that dismisses creative thinking and drives out good ideas.

- It is also surprising that Humanitarian Logistics has more papers with Hypothetical data than Real data given the huge number of catastrophes that the globe experiences? 


\subsection{Function vs. Data Analysis Technique}

Table 13: Function vs. Data Analysis Technique.

\begin{tabular}{|c|c|c|c|c|c|c|c|c|c|c|c|c|c|c|}
\hline $\begin{array}{l}\text { Function vs. Data } \\
\text { Analysis Technique }\end{array}$ & $\begin{array}{l}\frac{n}{0} \\
\frac{0}{0} \\
\sum_{00}^{0} \\
: 0 \\
0 \\
0 \\
0\end{array}$ & 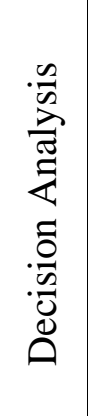 & 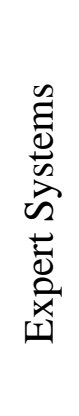 & 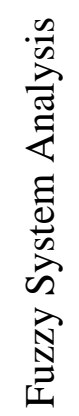 & 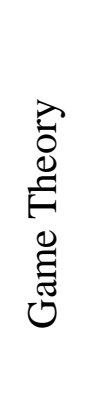 & . & 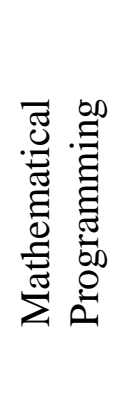 & $\begin{array}{l}\frac{n}{0} \\
\frac{0}{0} \\
\sum^{2} \\
0 \\
\frac{0}{1} \\
\frac{1}{0} \\
\frac{0}{0} \\
z\end{array}$ & 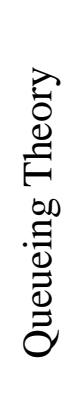 & 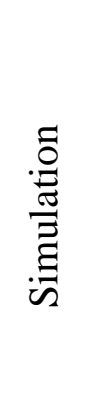 & 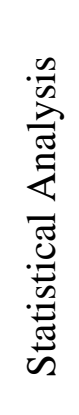 & 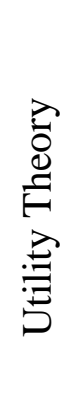 & 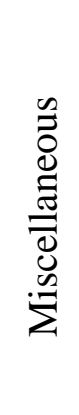 & 䒕 \\
\hline $\begin{array}{l}\text { Casualty } \\
\text { Management }\end{array}$ & 0 & 0 & 0 & 0 & 0 & 1 & 12 & 0 & 2 & 1 & 0 & 0 & 1 & 17 \\
\hline $\begin{array}{l}\text { Decision Making } \\
\text { Process }\end{array}$ & 0 & 6 & 5 & 0 & 1 & 0 & 4 & 0 & 0 & 4 & 3 & 2 & 3 & 28 \\
\hline Evacuation & 0 & 0 & 0 & 0 & 0 & 1 & 14 & 1 & 0 & 4 & 0 & 1 & 0 & 21 \\
\hline $\begin{array}{l}\text { Humanitarian } \\
\text { Logistics }\end{array}$ & 2 & 0 & 0 & 0 & 2 & 0 & 36 & 0 & 0 & 4 & 0 & 3 & 4 & 51 \\
\hline Prevention/Mitigation & 0 & 5 & 0 & 3 & 7 & 1 & 2 & 0 & 0 & 2 & 0 & 2 & 1 & 23 \\
\hline Restoration/Recovery & 0 & 1 & 1 & 0 & 0 & 1 & 2 & 1 & 0 & 0 & 0 & 0 & 0 & 6 \\
\hline Total & 2 & 12 & 6 & 3 & 10 & 4 & 70 & 2 & 2 & 15 & 3 & 8 & 9 & 146 \\
\hline
\end{tabular}

The review of data in Table 13 shows that mathematical programming has the highest number of papers (70 papers) and is primarily used for casualty management (12 papers), evacuations (14 papers) and humanitarian logistics (36) papers. These 62 out of 70 papers account for $88.57 \%$ of the papers in mathematical programming. These areas lend themselves for easy mathematical formulations. So those researchers with expertise in mathematical programming can benefit from their research focus in these areas.

Half of all papers use some form of programming modeling. We should note that programming is usually a system of constraints and an objective function to optimize. In disaster management, the highest form of objective function would be to prevent the disaster from occurring. Below that would be to mitigate the severity of the disaster which cannot be prevented. This concept can be extended to the "during" phase as well as the "after" phase. 
Mathematical Programming techniques include: Linear Programming, Nonlinear programming, Dynamic programming, Integer programming, Integer Nonlinear Programming, Mixed integer linear programming, Mixed Integer nonlinear programming, and Stochastic Programming.

Some other observations include:

- If risk or stochastic properties are not included, then the model is limited by the assumption of certainty throughout the complete set of interacting variables.

- Game theory was used seven times for prevention and mitigation. Five out of the seven papers study terrorism. Game theory makes good sense when terrorism is involved but in games against nature, its use is questionable.

- The researchers whose strong suite is stochastic systems may find some of the other techniques of interest like bidding models, decision analysis, game theory, queueing theory, statistical analysis and utility theory.

- Decision making process has used a variety of techniques including decision analysis (6 papers) and expert systems (5 papers).

- Goal Programming could be an important technique to study disaster problems with multiple objectives. This technique is missing.

\subsection{Data Type vs. Data Analysis Technique}

Table 14: Data Type vs. Data Analysis Technique.

\begin{tabular}{|c|c|c|c|c|c|c|c|c|c|c|c|c|c|c|}
\hline $\begin{array}{l}\text { Data Type vs. } \\
\text { Data Analysis } \\
\text { Technique }\end{array}$ & $\begin{array}{l}\frac{n}{0} \\
\frac{0}{0} \\
\sum_{00} \\
.0 \\
0 \\
0\end{array}$ & 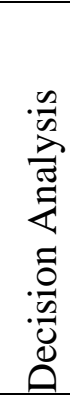 & 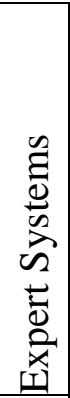 & 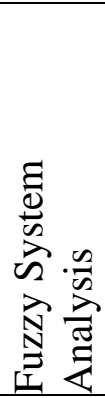 & $\begin{array}{l}\overrightarrow{0} \\
\stackrel{0}{0} \\
\stackrel{E}{E} \\
\ddot{E} \\
\tilde{E} \\
0\end{array}$ & 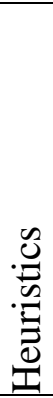 & 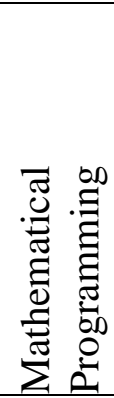 & 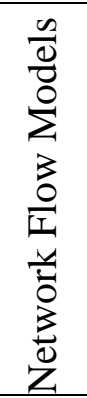 & 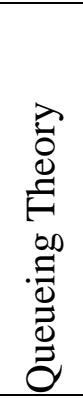 & 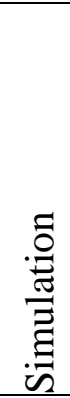 & 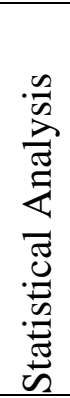 & 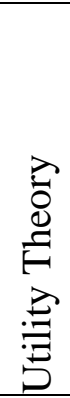 & 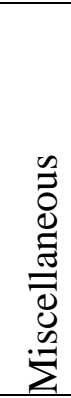 & $\stackrel{\pi}{0}$ \\
\hline $\mathrm{F} \& \mathrm{~A}$ & 0 & 2 & 2 & 2 & 1 & 0 & 2 & 0 & 0 & 1 & 3 & 1 & 2 & 16 \\
\hline Hypothetical & 2 & 5 & 2 & 0 & 4 & 2 & 34 & 0 & 2 & 8 & 0 & 5 & 2 & 66 \\
\hline Real & 0 & 5 & 2 & 1 & 1 & 2 & 34 & 2 & 0 & 6 & 0 & 0 & 4 & 57 \\
\hline No Data & 0 & 0 & 0 & 0 & 4 & 0 & 0 & 0 & 0 & 0 & 0 & 2 & 1 & 7 \\
\hline Total & 2 & 12 & 6 & 3 & 10 & 4 & 70 & 2 & 2 & 15 & 3 & 8 & 9 & 146 \\
\hline
\end{tabular}


Table 14 describes the solution domain which is a cross tabulation of data type vs. data analysis technique. There is a paucity of research work based on F\&A data. Hypothetical (66 papers) and real (57 papers) are close. But still we need to move away from using the Hypothetical data to bring more realism in disaster research and to make it acceptable to the administrators. As previously pointed out, Hypothetical data must be based on some aspect of reality. Authors using such data must be challenged to explain what premises they used to model the hypothetical.

\subsection{Disaster Type vs. Data Analysis Technique.}

Table 15: Disaster Type vs. Data Analysis Technique.

\begin{tabular}{|c|c|c|c|c|c|c|c|c|c|c|c|c|c|c|}
\hline $\begin{array}{l}\text { Disaster Type vs. Data } \\
\text { Analysis Technique }\end{array}$ & $\begin{array}{l}\frac{n}{0} \\
\frac{0}{0} \\
\sum_{0.0} \\
: \equiv \\
: 0 \\
0 \\
0 \\
0\end{array}$ & 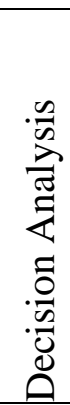 & 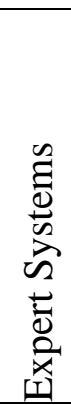 & 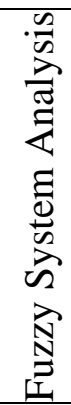 & 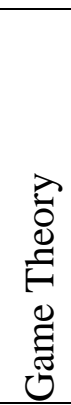 & 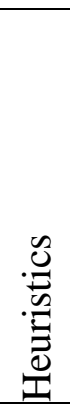 & 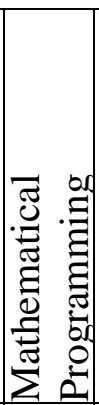 & $\begin{array}{l}0 \\
0 \\
0 \\
0 \\
0 \\
0 \\
0 \\
0 \\
\overline{0} \\
0 \\
0 \\
0 \\
0\end{array}$ & 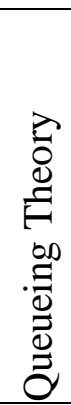 & 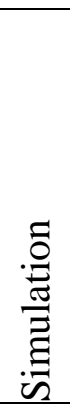 & 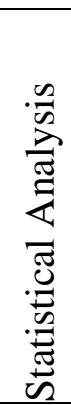 & 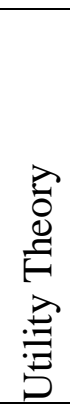 & 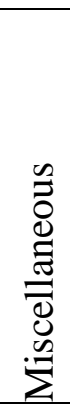 & $\stackrel{\pi}{0}$ \\
\hline Accidents & 0 & 3 & 0 & 0 & 1 & 0 & 3 & 0 & 0 & 0 & 0 & 1 & 0 & 8 \\
\hline Earthquake & 0 & 2 & 1 & 2 & 1 & 0 & 20 & 1 & 0 & 3 & 1 & 1 & 1 & 33 \\
\hline Epidemic & 0 & 1 & 1 & 0 & 0 & 0 & 2 & 0 & 0 & 1 & 0 & 0 & 2 & 7 \\
\hline Flood & 0 & 0 & 0 & 0 & 0 & 0 & 3 & 0 & 0 & 2 & 0 & 2 & 0 & 7 \\
\hline General & 2 & 4 & 3 & 1 & 3 & 3 & 28 & 1 & 2 & 8 & 1 & 3 & 4 & 63 \\
\hline Hurricane & 0 & 0 & 1 & 0 & 0 & 0 & 15 & 0 & 0 & 1 & 1 & 2 & 2 & 22 \\
\hline Landslide & 0 & 0 & 0 & 0 & 0 & 0 & 0 & 0 & 0 & 1 & 0 & 0 & 0 & 1 \\
\hline Terrorism & 0 & 2 & 1 & 0 & 5 & 1 & 1 & 0 & 0 & 1 & 0 & 0 & 0 & 11 \\
\hline Wildfire & 0 & 0 & 0 & 0 & 0 & 0 & 1 & 0 & 0 & 0 & 0 & 0 & 0 & 1 \\
\hline Total & 2 & 12 & 7 & 3 & 10 & 4 & 73 & 2 & 2 & 17 & 3 & 9 & 9 & 153 \\
\hline
\end{tabular}

Table 15 is a cross tabulation of disaster type and data analysis technique. Terrorism is primarily studied using game theory assuming terrorist (attacker) is one player and the government (defender) is another player. Earthquakes and hurricanes have mostly used mathematical programming. Our previous comments apply here too as to when to use game theory and when not to use it. In the case of people against people it makes sense so that applies to people against government. 


\subsection{Disaster Type vs. Data Type}

Table 16: Disaster Type vs. Data Type.

\begin{tabular}{|l|l|l|l|l|l|}
\hline $\begin{array}{l}\text { Disaster Type } \\
\text { vs. Data Type }\end{array}$ & F\&A & Hypothetical & Real & $\begin{array}{l}\text { No } \\
\text { Data }\end{array}$ & Total \\
\hline Accidents & 0 & 3 & 5 & 0 & 8 \\
\hline Earthquake & 5 & 10 & 18 & 0 & 33 \\
\hline Epidemic & 0 & 1 & 6 & 0 & 7 \\
\hline Flood & 0 & 2 & 5 & 0 & 7 \\
\hline General & 9 & 35 & 16 & 3 & 63 \\
\hline Hurricane & 2 & 11 & 8 & 1 & 22 \\
\hline Landslide & 0 & 1 & 0 & 0 & 1 \\
\hline Terrorism & 0 & 6 & 3 & 3 & 12 \\
\hline Wildfire & 0 & 1 & 0 & 0 & 1 \\
\hline Total & 16 & 70 & 61 & 7 & 154 \\
\hline
\end{tabular}

Table 16 is a cross tabulation of Disaster Type and Data Type. It is noticeable that for earthquakes Real data has been used in 18 papers as compared to the use of Hypothetical data (10 papers). On the contrary, in case of hurricanes, the number of papers that use Hypothetical data is more (11 papers) as compared to papers that use Real data (8 papers). General papers have used Hypothetical data in 35 papers as compared to Real data (16 papers). This is somewhat understandable because the general papers do not focus on any one type of disaster so the papers depend on Hypothetical data. Increasingly, we see the need to challenge Hypothetical data models. This is a further rebuke of General Models. Some other observations include:

- Terrorism, that primarily used game theory for analysis have used Hypothetical data. It is probably difficult to get any Real data because attackers' strategies may not be known.

- More papers in epidemics, floods and accidents have used the Real data. We are not sure but it could be the ease with which the data can be collected for these disasters.

\section{Implications for Managers}

Managing disaster is unlike managing a business organization, not only because the goals and objectives are different, but also because there is a single organization in any country that manages disasters, for example, the Federal Emergency Management association (FEMA) in the U.S.A., and Australian Emergency Management Arrangements in Australia. FEMA has well established processes 
for managing all phases of a disaster. So the research models have to be developed in support of the current processes or the models must have the power to convince the administrators that a given process needs to be changed. There will be a "dis-connect" if this is not done. Since the user is only one entity (e.g. FEMA), unless that entity is convinced that proposed models really solve the problem, there will be no acceptance. Since there is only one user of these models it should be rather easy to identify problems, collect data, analyze them and propose a solution.

The two attributes that are of primary importance to the administrators include "functions", and "type of disasters". Administrators are typically responsible for one or more specified functions that broadly include among others: policy planning, plan development, forecasting, prevention, mitigation, evacuation, shelter locations, procurement, inventory management, distribution of supplies, medical care of disaster victims, transportation of disaster victims, and coordination with other government and non-government organizations. In this research, we have grouped activities and functions for managing disasters in six major categories as mentioned in Section 3.1.1. These categories are further subdivided into 33 subcategories as discussed earlier in Sections 4.1 to 4.6. This categorization will help an administrator to find references on particular topics of interest.

Take, for example, the evacuation function. Evacuation includes many activities that include among others: how far in advance to issue warning signals, what is the impact of these signals, movement of traffic, use of public transportations and/or private cars for evacuation and shelter location. Some people do not evacuate in spite of warnings. So understanding individual behavior and the influence of social networks is important. Experience with near-miss events also plays an important role. An administrator will be able to identify appropriate research and make strategic and operational decisions based on research findings.

The type of disaster is another important parameter that is important to administrators. Based on our categorization, as described above, it will be easy for administrators to locate disaster-specific research papers. The administrators' interest in different types of disasters may be based on their work related responsibilities. For example, an administrator in Florida will have more interest in hurricanes whereas an administrator in California will have more interest in earthquakes. Similarly, there are specially qualified people who deal with disasters involving hazardous materials (HAZMAT) and those 
who deal with terrorism. These disasters have different origins and different impacts. Terrorism is preventable if the surveillance system is strong and warning signals are analyzed in time and preventive action is taken; HAZMAT is a result of human error and negligence; whereas hurricanes are natural disaster and inevitable.

\section{Summary, Conclusions and Directions for Future Research}

In this paper, we have reviewed disaster management research published in twenty five major Operations Management, Management Science, Operations Research, Supply Chain Management and Transportation/ Logistics journals over a span of 57 years - from 1957 to 2014. The scope of this paper is to assess and present the macro level "architectural blue print" of this evolving field rather than review individual papers in depth. We expect to attract new researchers in this field; and also hope for greater participation of disaster management administrators in research and practice.

The papers that have been reviewed here primarily revolved around the following five attributes of a disaster: disaster management functions, time of disaster, type of disaster, data type and data analysis techniques. Cross tabulation of data among these five attributes provide important insights. We have coined the following two new terms in this paper: "disaster domain" based on function, time and type of disaster and "solution domain" based on data type and data analysis technique. Disaster domain is likely to be of primary interest to administrators whereas the researchers' focus will be on solution domain.

It is evident from this review that the underlying thread for effective disaster management is primarily systems integration. These systems consist of many organizations that come together for relief operations with their own beliefs, convictions, resources, goals and objectives. These systems consist of sequential and overlapping functions which include prevention/mitigation, evacuation, humanitarian logistics, casualty management and restoration/recovery. These systems are constrained by technology and environmental considerations (physical, social, economic and political). These systems transcend national boundaries. These systems deal with uncertainty and imperfect information. These systems do not focus on traditional goals of profit making. The disaster management systems have all of these characteristics. So a system oriented approach is essential for disaster management. The systems-oriented approach is not new. It has been advocated for at least last five decades. Gupta 
and Roth (2007) have reviewed Martin K. Starr's contribution to operations management with a focus on systems integration and inter-functional coordination that can be used for catastrophe avoidance.

Based on our findings and our convictions and beliefs about disaster research we make the following recommendations for future research. These recommendations are not mandates. The authors do not expect that every paper will have applicability of each and every one of these recommendations. It would be impossible for future researchers to attain all of these goals in any one paper. Our hope is that over time and across many research efforts, a body of work will emerge (facilitated by these guidelines), that will represent a robust disaster research base.

1. It is preferable to use Real data and more F\&A data so that research findings make their way in practice. Use of the Real and F\&A data are likely to inspire and instil more confidence among the administrators. To the extent possible, the authors should describe how the data used in the model will be collected.

2. We found in our review that sometimes the authors made claims that their models could be used in any disaster situation. However, disasters are so different that one model may not fit all. For examples, hurricanes are completely different from earthquakes. Hurricanes are relatively slow onset disasters whereas earthquakes are classified as sudden onset disasters. There is enough lead time for substantial preparation (including evacuation) in the case of a hurricane. The problem of generalizing without substantiating similarities can lead to erroneous conclusions and unsuitable applications. These may be avoided if the researchers identify the five disaster parameters in their research papers. The five parameters are meant to provide a structure that could be used to help frame future research as well as to evaluate present research.

3. It is recommended that a brief description of the current processes recommended and employed by the relevant disaster management agency (e.g., FEMA in the USA) be included. Researchers have to develop their models in support of the current processes. The researchers' models must have the power to convince administrators that a given process needs to be used as is or modified before use.

4. The recovery/restoration field is understudied and needs more attention. The researchers while working on recovery/restoration issues may also like to analyze whether the disaster situation could have been prevented (and/or alleviated) and if so how? 
5. Hospitals' surge capacity is an important issue in the casualty management that needs researchers' attention.

6. Disasters are high impact and low probability events. There are very interesting research opportunities in studying the impact vs. event probability matrix.

7. We would like to see more research in prevention/mitigation. Sound prevention/mitigation strategies will reduce the efforts and resources required in other phases of disaster management.

8. We propose that additional survey papers be written that focus on various functions. In our review we found papers by Abidi et al. (2014) and Day (2014) who study performance measurement, and resilience respectively in disaster management.

9. In humanitarian logistics there is a need to have more integrated models that simultaneously take into account the location of distribution centers, inventory positioning and distribution logistics.

10. Study of the impact of warning signals during evacuation is an important research topic. Individuals' preference to evacuate or not is important in situations when evacuation is not mandatory. Influence of social circles (what friends, neighbors and relatives are doing) and experiences with near - miss events influences evacuee's behavior. The "cry wolf" syndrome after the issuance of a warning also influences evacuees' behavior.

11. Finding and solving potential research problems in the chaos of the "during" phase is an area ripe for research. Investment in data collection technology is essential in the "during" phase. For example, finding who needs what (medical aid, food supplies, etc.) is dependent upon communication mobility and intelligence reliability. Supply chains must pinpoint accurately where need fulfillment is required (often called the last mile).

\section{REFERENCES}

Abdelghany, A., K. Abdelghany, H. Mahmassani, W. Alhalabi. 2014. Modeling framework for optimal evacuation of large-scale crowded pedestrian facilities. European Journal of Operational Research 237(3) 1105-1118.

Abidi, H., S. de Leeuw, M. Klumpp. 2014. Humanitarian Supply Chain Performance Management: A Systematic Literature Review. Supply Chain Management: An International Journal 19(5/6) 592608.

Abounacer, R., M. Rekik, J. Renaud. 2014. An exact solution approach for multi-objective locationtransportation problem for disaster response. Computers \& Operations Research 41 83-93. 
Adida, E., P.C.C. DeLaurentis, M.A. Lawley. 2011. Hospital stockpiling for disaster planning. IIE Transactions 43(5) 348-362.

Aksu, D.T., L. Özdamar. 2014. A mathematical model for post-disaster road restoration: Enabling accessibility and evacuation. Transportation Research: Part E 61 56-67.

Albores, P., D. Shaw. 2008. Government preparedness: Using simulation to prepare for a terrorist attack. Computers \& Operations Research 35(6) 1924-1943.

Altay, N., W.G. Green III. 2006. OR/MS research in disaster operations management. European Journal of Operational Research 175(1) 475-493.

Altay, N., R. Pal. 2014. Information Diffusion among Agents: Implications for Humanitarian Operations. Production and Operations Management 23(6) 1015-1027.

Amailef, K., J. Lu. 2013. Ontology-supported case-based reasoning approach for intelligent mGovernment emergency response services. Decision Support Systems 55(1) 79-97.

An, S., N. Cui, X. Li, Y. Ouyang. 2013. Location planning for transit-based evacuation under the risk of service disruptions. Transportation Research: Part B 54 1-16.

Araz, O.M., T. Lant, J.W. Fowler, M. Jehn. 2013. Simulation modeling for pandemic decision making: A case study with bi-criteria analysis on school closures. Decision Support Systems 55(2) 564-575.

Arbel, A. 1980. A planning model for crisis management in the tourism sector. European Journal of Operational Research 5(2) 77-85.

Arora, H., T.S. Raghu, A. Vinze. 2010. Resource allocation for demand surge mitigation during disaster response. Decision Support Systems 50(1) 304-315.

Bagchi, A., J.A. Paul, M. Maloni. 2011. Improving bid efficiency for humanitarian food aid procurement. International Journal of Production Economics 134(1) 238-245.

Bagchi, A., J.A. Paul. 2014. Optimal Allocation of Resources in Airport Security: Profiling vs. Screening. Operations research 62(2) 219-233.

Balcik B., D. Ak. 2013. Supplier Selection for Framework Agreements in Humanitarian Relief. Production and Operations Management 23(6) 1028-1041.

Balcik, B., B.M. Beamon, C.C. Krejci, K.M. Muramatsu, M. Ramirez. 2010. Coordination in humanitarian relief chains: Practices, challenges and opportunities. International Journal of Production Economics 126(1) 22-34.

Bana e Costa, C.A., C.S. Oliveira, V. Vieira. 2008. Prioritization of bridges and tunnels in earthquake risk mitigation using multicriteria decision analysis: Application to Lisbon. OMEGA 36(3) 442450 .

Barbarosoğlu, G., Y. Arda. 2004. A two-stage stochastic programming framework for transportation planning in disaster response. Journal of the Operational Research Society 55(1) 43-53.

Barbarosoğlu, G., L. Özdamar, A. Çevik. 2002. An interactive approach for hierarchical analysis of helicopter logistics in disaster relief operations. European Journal of Operational Research 140(1) 118-133.

Baykal-Gürsoy, M., Z. Duan, H.V. Poor, A. Garnaev. 2014. Infrastructure security games. European Journal of Operational Research 239(2) 469-478. 
Belardo, S.J. Harrald, W.A. Wallace, J. Ward. 1984. A Partial Covering Approach to Siting Response Resources for Major Maritime Oil Spills. Management Science 30(10) 1184-1196.

Belardo, S., H.L. Pazer, W.A. Wallace, W.D. Danko. 1983. Simulation of a crisi management information network: a serendipitous evaluation. Decision Sciences 14(4) 588-606.

Ben-Tal, A., B.D. Chung, S.R. Mandala, T. Yao. 2011. Robust optimization for emergency logistics planning: Risk mitigation in humanitarian relief supply chains. Transportation Research: Part B 45(8) 1177-1189.

Beraldi, P., M.E. Bruni. 2009. A probabilistic model applied to emergency service vehicle location. European Journal of Operational Research 196(1) 323-331.

Berger, J., A. Boukhtouta, A. Benmoussa, O. Kettani. 2012. A new mixed-integer linear programming model for rescue path planning in uncertain adversarial environment. Computers \& Operations Research 39(12) 3420-3430.

Berman, O., A. Gavious. 2007. Location of terror response facilities: A game between state and terrorist. European Journal of Operational Research 117(2) 1113-1133.

Berman, O., A. Gavious, M.B.C. Menezes. 2012. Optimal response against bioterror attack on airport terminal. European Journal of Operational Research 219(2) 415-424.

Berndt, D.J., J.W. Fisher, J.G. Craighead, A.R. Hevner, S. Luther, J. Studnicki. 2007. The role of data warehousing in bioterrorism surveillance. Decision Support Systems 43(4) 1383-1403.

Besiou, M., A.J. Pedraza-Martinez, L.N. Van Wassenhove. 2014. Vehicle Supply Chains in Humanitarian Operations: Decentralization, Operational Mix, and Earmarked Funding. Production and Operations Management 23(11) 1950-1965.

Bhattacharya, S., S. Hasija, L.N. Van Wassenhove. 2014. Designing Efficient Infrastructural Investment and Asset Transfer Mechanisms in Humanitarian Supply Chains. Production and Operations Management 23(9) 1511-1521.

Bish, D.R. 2011. Planning for a bus-based evacuation. OR Spectrum 33(3) 629-654.

Bish, D.R., E. Agca, R. Glick. 2011. Decision support for hospital evacuation and emergency response. Annals of Operations Research 221(1) 89-106.

Bish, D.R., H.D. Sherali. 2013. Aggregate-level demand management in evacuation planning. European Journal of Operational Research 224(1) 79-92.

Bish, D.R., H.D. Sherali, A.G. Hobeika. 2014. Optimal evacuation planning using staging and routing. Journal of the Operational Research Society 65 124-140.

Boin, Arjen, Peter Kelle and D. Clay Whybark. 2010. Editors of the Special Issue, Improving Disaster Supply Chain Management - Key supply chain factors for humanitarian relief, International Journal of Production Economics 126 (1) 1-144.

Bozorgi-Amiri, A., M.S. Jabalameli, S.M.J. Mirzapour Al-e-Hashem. 2013. A multi-objective robust stochastic programming model for disaster relief logistics under uncertainty. OR Spectrum 35(4) 905-933.

Bretschneider, S., A. Kimms. 2012. Pattern-based evacuation planning for urban areas. European Journal of Operational Research 216(1) 57-69. 
Bui, T.X., S.R. Sankaran. 2001. Design considerations for a virtual information center for humanitarian assistance/disaster relief using workflow modeling. Decision Support Systems 31(2) 165-179.

Campbell, A.M., P.C. Jones. 2011. Prepositioning supplies in preparation for disasters. European Journal of Operational Research 209(1) 156-165.

Campbell, A.M., D. Vandenbussche, W. Hermann. 2008. Routing for Relief Efforts. Transportation Science 42(2) 127-145.

Chakravarty, A.K. 2011. A contingent plan for disaster response. International Journal of Production Economics 134(1) 3-15.

Chakravarty, A.K. 2014. Humanitarian relief chain: Rapid response under uncertainty. International Journal of Production Economics 151 146-157.

Chan, C.W., L.V. Green, Y. Lu, N. Leahy, R. Yurt. 2013. Prioritizing Burn-Injured Patients During a Disaster. Manufacturing \& Service Operations Management 15(2) 170-190.

Chang, M.S., Y.L. Tseng, J.W. Chen. 2007. A scenario planning approach for the flood emergency logistics preparation problem under uncertainty. Transportation Research: Part E 43(6) 737-754.

Charles, A., M. Lauras. 2011. An enterprise modelling approach for better optimisation modelling: application to the humanitarian relief chain coordination problem. OR Spectrum 33(3) 815-841.

Chen, L., E. Miller-Hooks. 2008. The building evacuation problem with shared information. Naval Research Logistics 55(4) 363-376.

Chen, L., E. Miller-Hooks. 2012. Optimal team deployment in urban search and rescue. Transportation Research: Part B 46(8) 984-999.

Chen, X., F.B. Zhan. 2008. Agent-based modelling and simulation of urban evacuation: relative effectiveness of simultaneous and staged evacuation strategies. Journal of the Operational Research Society 59(1) 25-33.

Chiu, Y., H. Zheng. 2007. Real-time mobilization decisions for multi-priority emergency response resources and evacuation groups: Model formulation and solution. Transportation Research: Part E 43(6) 710-736.

Chiu, Y.C., H. Zheng, J. Villalobos, B. Gautam. 2007. Modeling no-notice mass evacuation using a dynamic traffic flow optimization model. IIE Transactions 39(1) 83-94.

Cook, W.D. 1977. A Model for the Evacuation of Casualties from a Field Hospital During a Crisis. Journal of the Operational Research Society 28 963-974.

Cotta, C. 2011. Effective patient prioritization in mass casualty incidents using hyperheuristics and the pilot method. OR Spectrum 33(3) 699-720.

Current, J., M. O'Kelly. 1992. Locating Emergency Warning Sirens. Decision Sciences 23(1) 221-234.

Dai, J., S. Wang, X. Yang. 1994. Computerized support systems for emergency decision making. Annals of Operations Research 51(7) 313-325.

Das, T.K., A.A. Savachkin, Y. Zhu. 2008. A large-scale simulation model of pandemic influenza outbreaks for development of dynamic mitigation strategies. IIE Transactions 40(9) 893-905. 
Das, R., S. Hanaoka. 2014. Relief inventory modeling with stochastic lead-time and demand. European Journal of Operational Research 235(3) 616-623.

Davis, L.B., F. Samanlioglu, X. Qu, S. Root. 2013. Inventory planning and coordination in disaster relief efforts. International Journal of Production Economics 141(3) 561-573.

Day, J.M. 2014. Fostering emergent resilience: the complex adaptive supply network of disaster relief. International Journal of Production Research 52(7) 1970-1988.

Day, J.M., S.A. Melnyk, P.D. Larson, E.W. Davis, D.C. Whybark. 2012. Humanitarian and Disaster Relief Supply Chains: A Matter of Life and Death. Journal of Supply Chain Management 48(21) 21-36.

De Angelisa, V., M. Mecolia, C. Nikoib, G. Storchi. 2007. Multiperiod integrated routing and scheduling of World Food Programme cargo planes in Angola. Computers \& Operations Research 34(6) 1601-1615.

Dean, M.D., S.K. Nair. 2014. Mass-casualty triage: Distribution of victims to multiple hospitals using the SAVE model. European Journal of Operational Research 238(1) 363-373.

de Silva, F.N., R.W. Eglese. 2000. Integrating simulation modelling and GIS: spatial decision support systems for evacuation planning. Journal of the Operational Research Society 51(4) 423-430.

de Treville, S., I. Smith, A. Rölli, V. Arnold. 2006. Applying operations management logic and tools to save lives: A case study of the world health organization's global drug facility. Journal of Operations Management 24(4) 397-406.

Dillon, R.L., C.H. Tinsley. 2008. How Near-Misses Influence Decision Making Under Risk: A Missed Opportunity for Learning. Management Science 54(8) 1425-1440.

Dodo, A., R.A. Davidson, N. Xub, L.K. Nozick. 2007. Application of regional earthquake mitigation optimization. Computers \& Operations Research 34(8) 2478-2494.

Doerner, K.F., W.J. Gutjahr, P.C. Nolz. 2009. Multi-criteria location planning for public facilities in tsunami-prone coastal areas. OR Spectrum 31(3) 651-678.

Doerner, K.F., W.J. Gutjahr, L. Van Wassenhove. 2011. Special issue on optimization in disaster relief. OR Spectrum 33(3) 445-449.

Drezner, T., Z. Drezner, S. Salhi. 2006. A multi-objective heuristic approach for the casualty collection points location problem. Journal of the Operational Research Society 57 727-734.

Duanmu, J., M. Chowdhury, K. Taaffe, C. Jordan. 2012. Buffering in evacuation management for optimal traffic demand distribution. Transportation Research: Part E 48(3) 684-700.

Duque, P.M., K. Sörensen. 2011. A GRASP metaheuristic to improve accessibility after a disaster. $O R$ Spectrum 33(3) 525-542.

Earthquake.usgs.gov/research/earlywarning

Edrissi, A., H. Poorzahedy, H. Nassiri, M. Nourinejad. 2013. A multi-agent optimization formulation of earthquake disaster prevention and management. European Journal of Operational Research 229(1) 261-275.

Eftekhar, M., A. Masini, A. Robotis, L.N. Van Wassenhove. 2014. Vehicle Procurement Policy for Humanitarian Development Programs. Production and Operations Management 23(6) 951-964. 
Egan, M.J. 2010. Private goods and services contracts: Increased emergency response capacity or increased vulnerability?. International Journal of Production Economics 126(1) 35-45.

Eiselt, H.A., V. Marianov. 2012. Mobile phone tower location for survival after natural disasters. European Journal of Operational Research 216(3) 563-572.

Ekici, A., P. Keskinocak, J.L. Swann. 2014. Modeling Influenza Pandemic and Planning Food Distribution. Manufacturing \& Service Operations Management 16(1) 11-27.

Ergun, Ö., L. Gui, J.L. Heier Stamm, P. Keskinocak, J. Swann. 2014. Improving Humanitarian Operations through Technology-Enabled Collaboration. Production and Operations Management 23(6) 1002-1014.

Ermoliev, Y.M., T.Y. Ermolieva, G.J. MacDonald, V.I. Norkin, A. Amendola. 2000. A system approach to management of catastrophic risks. European Journal of Operational Research 122(2) 452-460.

Faturechi, R., E. Miller-Hooks. 2014. Travel time resilience of roadway networks under disaster. Transportation Research: Part B 70 47-64.

FEMA: Comprehensive Preparedness Guide (CPG) 101 Version 2, November 2010.

Fishburn, P.C. 1984. Equity Axioms for Public Risks. Operations Research 32(4) 901-908.

Fogli, D., G. Guida. 2013. Knowledge-centered design of decision support systems for emergency management. Decision Support Systems 55(1) 336-347.

Fogli, D., G. Guida. 1995. GENIE: A decision support system for crisis negotiations. Decision Support Systems 14(4) 369-391.

Galindo, G., R. Batta. 2013. Review of recent developments in OR/MS research in disaster operations management. European Journal of Operational Research 230(2) 201-211.

Gatignon, A., L.N. Van Wassenhove, A. Charles. 2010. The Yogyakarta earthquake: Humanitarian relief through IFRC's decentralized supply chain. International Journal of Production Economics 126(1) 102-110.

Glickman, T.S., D.B. Rosenfield. 1984. Risks of Catastrophic Derailments Involving the Release of Hazardous Materials. Management Science 30(4) 503-511.

Golany, B., E.H. Kaplan, A. Marmur, U.G. Rothblum. 2009. Nature plays with dice - terrorists do not: Allocating resources to counter strategic versus probabilistic risks. European Journal of Operational Research 192(1) 198-208.

Gong, Q., R. Batta. 2007. Allocation and reallocation of ambulances to casualty clusters in a disaster relief operation. IIE Transactions 39(1) 27-39.

Goerigk, M., B. Grün. 2014. A robust bus evacuation model with delayed scenario information. $O R$ Spectrum 36(4) 923-948.

Görmez, N., M. Köksalan, F.S. Salman. 2011. Locating disaster response facilities in Istanbul. Journal of the Operational Research Society 62 1239-1252.

Gottinger, H.W., 1998. Monitoring pollution accidents. European Journal of Operational Research 104 (1) 18-30. 
Gralla, E., J. Goentzel, C. Fine. 2014. Assessing Trade-offs among Multiple Objectives for Humanitarian Aid Delivery Using Expert Preferences. Production and Operations Management 23(6) 978-989.

Grechuk, B., M. Zabarankin. 2014. Risk averse decision making under catastrophic risk. European Journal of Operational Research 239(1) 166-176.

Gregory, W.J., G. Midgley. 2000. Planning for disaster: developing a multi-agency counselling service. Journal of the Operational Research Society 51(3) 278-290.

Gupta, S., A.V. Roth. 2007. Martin K. Starr: A visionary proponent for system integration, modular production, and catastrophe avoidance. Production and Operations Management 16(1) 1-12.

Günneç, D., F.S. Salman. 2011. Assessing the reliability and the expected performance of a network under disaster risk. OR Spectrum 33(3) 499-523.

Haastrup, P. 1994. Overview of problems of risk management of accidents with dangerous chemicals in Europe. European Journal of Operational Research 75(3) 488-498.

Haghighi, P.D., F. Burstein, A. Zaslavsky, P. Arbon. 2013. Development and evaluation of ontology for intelligent decision support in medical emergency management for mass gathering. Decision Support Systems 54(2) 1192-1204.

Hamacher, H.W., S. Tufekci. 1987. On the use of lexicographic min cost flows in evacuation modeling. Naval Research Logistics 34 487-503.

Hamacher, H.W., S. Heller, B. Rupp. 2013. Flow location (FlowLoc) problems: dynamic network flows and location models for evacuation planning. Annals of Operations Research 207(1) 161180 .

Hammerton, M., M. W. Jones-Lee, V. Abbott. 1982. Technical Note-Equity and Public Risk: Some Empirical Results. Operations Research 30(1) 203-207.

Hasan, S., S.V. Ukkusuri. 2011. A threshold model of social contagion process for evacuation decision making. Transportation Research: Part B 45(10) 1590-1605.

Hausken, K., J. Zhuang. 2012. The timing and deterrence of terrorist attacks due to exogenous dynamics. Journal of the Operational Research Society 63 726-735.

Hausken, K., J. Zhuang. 2013. The impact of disaster on the strategic interaction between company and government. European Journal of Operational Research 225(2) 363-376.

Hausken, K., J. Zhuang. 2016. The strategic interaction between a company and the government surrounding disasters. Annals of Operations Research 237(1) 27-40.

Heaslip, G., A.M. Sharif, A. Althonayan. 2012. Employing a systems-based perspective to the identification of inter-relationships within humanitarian logistics. International Journal of Production Economics 139(2) 377-392.

Hiete, M., M. Merz, T. Comes, F. Schultmann. 2012. Trapezoidal fuzzy DEMATEL method to analyze and correct for relations between variables in a composite indicator for disaster resilience. $O R$ Spectrum 34(4) 971-995. 
Holguín-Veras, J., M. Jaller, L.N. Van Wassenhove, N. Pérez, T. Wachtendorf. 2012. On the unique features of post-disaster humanitarian logistics. Journal of Operations Management 30(7-8) 494506.

Holguín-Veras, J., N. Pérez, M. Jaller, L.N. Van Wassenhove, F. Aros-Vera. 2013. On the appropriate objective function for post-disaster humanitarian logistics models. Journal of Operations Management 31(5) 262-280.

Hu, Z.H., J.B. Sheu. 2013. Post-disaster debris reverse logistics management under psychological cost minimization. Transportation Research: Part B 55 118-141.

Huang, R., S. Kim, M.B..C. Menezes. 2010. Facility location for large-scale emergencies. Annals of Operations Research 181(1) 271-286.

Huang, M., K. Smilowitz, B. Balcik. 2012. Models for relief routing: Equity, efficiency and efficacy. Transportation Research: Part E 48(1) 2-18.

Huang, M., K.R. Smilowitz, B. Balcik. 2013. A continuous approximation approach for assessment routing in disaster relief. Transportation Research: Part B 50 20-41.

Huibregtse, O.L., S.P. Hoogendoorn, A. Hegyi, M.C.J. Bliemer. 2011. A method to optimize evacuation instructions. OR Spectrum 33(3) 595-627.

Hutchinson, T.P. 1976. Statistical Aspects of Injury Severity Part II: The Case of Several Populations but Only Three Grades of Injury. Transportation Science 10(3) 285-299.

Iakovou, E., Chi M. Ip, C. Douligeris, A. Korde. 1997. Optimal location and capacity of emergency cleanup equipment for oil spill response. European Journal of Operational Research 96(1) 72-80.

Iakovou, E., C. Douligeris, A. Korde. 1994. A synthesis of decision models for analysis, assessment, and contingency planning for oil spill incidents. OMEGA 22(5) 457-470.

Ishizaka, A., A. Labib. 2013. A hybrid and integrated approach to evaluate and prevent disasters. Journal of the Operational Research Society 65 1475-1489.

Jabbarzadeh, A., B. Fahimnia, S. Seuring. 2014. Dynamic supply chain network design for the supply of blood in disasters: A robust model with real world application. Transportation Research: Part E 70 225-244.

Jacobson, E.U., N.T. Argon, S. Ziya. 2012. Priority Assignment in Emergency Response. Operations Research 60(4) 813-832.

Jacobson, S.H., J.E. Kobza, E. Pohl. 2007. Editors' introduction: special issue on homeland security. IIE Transactions 39(1) 1-2.

Jenkins, L. 2000. Selecting scenarios for environmental disaster planning. European Journal of Operational Research 121(2) 275-286.

Jia, H., F. Ordóñez, M. Dessouky. 2007. A modeling framework for facility location of medical services for large-scale emergencies, IIE Transactions 39(1) 41-55.

Kananen, I., P. Korhonen, J. Wallenius, H. Wallenius. 1990. Multiple Objective Analysis of InputOutput Models for Emergency Management. Operations Research 38(2) 193-201.

Keeney, R.L. 1980. Equity and Public Risk. Operations Research 28(3) 527-534. 
Keeney, R.L., R.L. Winkler. 1985. Evaluating Decision Strategies for Equity of Public Risks. Operations Research 33(5) 955-970.

Kelle, P., H. Schneider, H. Yi. 2014. Decision alternatives between expected cost minimization and worst case scenario in emergency supply - Second revision. International Journal of Production Economics 157 250-260.

Kilic, A., M.C. Dincer, M.A. Gokce. 2013. Determining optimal treatment rate after a disaster. Journal of the Operational Research Society 65 1053-1067.

Kim, S.H., M.A. Cohen, S. Netessine, S. Veeraraghavan. 2010. Contracting for Infrequent Restoration and Recovery of Mission-Critical Systems. Management Science 56(9) 1551-1567.

Kim, J.K., R. Sharman, H. Raghav Rao, S. Upadhyaya. 2007. Efficiency of critical incident management systems: Instrument development and validation. Decision Support Systems 44(1) $235-250$.

Kimms, A., K.C. Maassen. 2011. Optimization and simulation of traffic flows in the case of evacuating urban areas. OR Spectrum 33(3) 571-593.

Kou, G., D. Ergu, Y. Shi. 2014. An integrated expert system for fast disaster assessment. Computers \& Operations Research 42 95-107.

Kumar, S., T. Havey. 2013. Before and after disaster strikes: A relief supply chain decision support framework. International Journal of Production Economics 145(2) 613-629.

Kunz, N., G. Reiner, S. Gold. 2014. Investing in disaster management capabilities versus prepositioning inventory: A new approach to disaster preparedness. International Journal of Production Economics 157 261-272.

Larson, R.C. 2007. Simple Models of Influenza Progression Within a Heterogeneous Population. Operations Research 55(3) 399-412.

Lazar Babu, V.L., L. Lin. 2006. Passenger grouping under constant threat probability in an airport security system. European Journal of Operational Research 168(2) 633-644.

Lee, E.K., S. Maheshwary, J. Mason, W. Glisson. 2006. Decision support system for mass dispensing of medications for infectious disease outbreaks and bioterrorist attacks. Annals of Operations Research 148(1) 25-53.

Lee, J., N. Bharosa, J. Yang, M. Janssen, H.R. Rao. 2011. Group value and intention to use - A study of multi-agency disaster management information systems for public safety. Decision Support Systems 50(2) 404-414.

Li, A.C.Y., L. Nozick, N. Xu, R. Davidson. 2012. Shelter location and transportation planning under hurricane conditions. Transportation Research: Part E 48(4) 715-729.

Li, J.P., R. Chen, J. Lee, H.R. Rao. 2013. A case study of private-public collaboration for humanitarian free and open source disaster management software deployment. Decision Support Systems 55(1) 1-11.

Li, J., Q. Li, C. Liu, S. Ullah Khan, N. Ghani. 2014. Community-based collaborative information system for emergency management. Computers \& Operations Research 42 116-124. 
Li, L., M. Jin, L. Zhang. 2011. Sheltering network planning and management with a case in the Gulf Coast region. International Journal of Production Economics 131(2) 431-440.

Liang, L., X. Wang, J. Gao. 2012. An option contract pricing model of relief material supply chain. OMEGA 40(5) 594-600.

Liberatore, F., M.P. Scaparra, M.S. Daskin. 2011. Analysis of facility protection strategies against an uncertain number of attacks: The stochastic R-interdiction median problem with fortification. Computers \& Operations Research 38(1) 357-366.

Liberatore, F., M.T. Ortuño, G. Tirado, B. Vitoriano, M.P. Scaparra. 2014. A hierarchical compromise model for the joint optimization of recovery operations and distribution of emergency goods in Humanitarian Logistics. Computers \& Operations Research 42 3-13.

Lim, M.K., A. Bassamboo, S. Chopra, M.S. Daskin. 2013. Facility Location Decisions with Random Disruptions and Imperfect Estimation. Manufacturing \& Service Operations Management 15(2) 239-249.

Liu, W., X. Xu, Z. Ren, Y. Peng. 2011. An emergency order allocation model based on multi-provider in two-echelon logistics service supply chain. Supply Chain Management: An International Journal 16(6) 391-400.

Liu, Y., Z. Fan, Y. Zhang. 2014. Risk decision analysis in emergency response: A method based on cumulative prospect theory. Computers \& Operations Research 42 75-82.

Liu, Y., Z. Fan, Y. Yuan, H. Li. 2014. A FTA-based method for risk decision-making in emergency response. Computers \& Operations Research 42 49-57.

Lodree Jr, E.J., S. Taskin. 2008. An insurance risk management framework for disaster relief and supply chain disruption inventory planning. Journal of the Operational Research Society $59674-$ 684.

Losada, C., M.P. Scaparra, J.R. O'Hanley. 2012. Optimizing system resilience: A facility protection model with recovery time. European Journal of Operational Research 217(3) 519-530.

Lu, C.C. 2013. Robust weighted vertex p-center model considering uncertain data: An application to emergency management. European Journal of Operational Research 230(1) 113-121.

Lu, C.C., J.B. Sheu. 2013. Robust vertex p-center model for locating urgent relief distribution centers. Computers \& Operations Research 40(8) 2128-2137.

Lu, Y., D. Yang. 2011. Information exchange in virtual communities under extreme disaster conditions. Decision Support Systems 50(2) 529-538.

MacGregor Smith, J. 1991. State-dependent queueing models in emergency evacuation networks. Transportation Research: Part B 25(6) 373-389.

Majeske, K.D., T.W. Lauer. 2012. Optimizing airline passenger prescreening systems with Bayesian decision models. Computers \& Operations Research 39(8) 1827-1836.

Mak, H., A.P. Mallard, T. Bui, G. Au. 1999. Building online crisis management support using workflow systems. Decision Support Systems 25(3) 209-224. 
Maon, F., A. Lindgreen, J. Vanhamme. 2009. Developing supply chains in disaster relief operations through cross-sector socially oriented collaborations: a theoretical model. Supply Chain Management: An International Journal 14(2) 149-164.

Martel, A., A. Benmoussa, M. Chouinard, W. Klibi, O. Kettani. 2013. Designing global supply networks for conflict or disaster support: the case of the Canadian Armed Forces. Journal of the Operational Research Society 64 577-596.

Matisziw, T.C., A.T. Murray. 2009. Modeling s-t path availability to support disaster vulnerability assessment of network infrastructure. Computers \& Operations Research 36(1) 16-26.

Matopoulos, A., G. Kovács, O. Hayes. 2014. Local Resources and Procurement Practices in Humanitarian Supply Chains: An Empirical Examination of Large-Scale House Reconstruction Projects. Decision Sciences 45(4) 621-646.

McCoy, J.H., M.L. Brandeau. 2011. Efficient stockpiling and shipping policies for humanitarian relief: UNHCR's inventory challenge. OR Spectrum 33(3) 673-698.

McCoy, J.H., H.L. Lee. 2014. Using Fairness Models to Improve Equity in Health Delivery Fleet Management. Production and Operations Management 23(6) 965-977.

Mendonça, D. 2007. Decision support for improvisation in response to extreme events: Learning from the response to the 2001 World Trade Center attack. Decision Support Systems 43(3) 952-967.

Mete, H.O., Z.B. Zabinsky. 2010. Stochastic optimization of medical supply location and distribution in disaster management. International Journal of Production Economics 126(1) 76-84.

Miller-Hooks, E., X. Zhang, R. Faturechi. 2012. Measuring and maximizing resilience of freight transportation networks. Computers \& Operations Research 39(7) 1633-1643.

Mills, A.F., N.T. Argon, S. Ziya. 2013. Resource-Based Patient Prioritization in Mass-Casualty Incidents. Manufacturing \& Service Operations Management 15(3) 361-377.

Min, H.S.J., W. Beyeler, T. Brown, Y.J. Son, A.T. Jones. 2007. Toward modeling and simulation of critical national infrastructure interdependencies. IIE Transactions 39(1) 57-71.

Modarres, M., B. Zarei. 2002. Application of network theory and AHP in urban transportation to minimize earthquake damages. Journal of the Operational Research Society 53(12) 1308-1316.

Moskowitz, H., P. Drnevich, O. Ersoy, K. Altinkemer, A. Chaturvedi. 2011. Using Real-Time Decision Tools to Improve Distributed Decision-Making Capabilities in High-Magnitude Crisis Situations. Decision Sciences 42(2) 477-493.

Mould G.I. 2001. Assessing Systems for Offshore Emergency Evacuation. Journal of the Operational Research Society 52(4) 401-408.

Nagarajan, M., D. Shaw, P. Albores. 2012. Disseminating a warning message to evacuate: A simulation study of the behaviour of neighbours. European Journal of Operational Research 220(3) 810-19.

Najafi, M., K. Eshghi, S. de Leeuw. 2014. A dynamic dispatching and routing model to plan/ re-plan logistics activities in response to an earthquake. OR Spectrum 36(2) 323-356.

Najafi, M., K. Eshghi, W. Dullaert. 2013. A multi-objective robust optimization model for logistics planning in the earthquake response phase. Transportation Research: Part E 49(1) 217-249. 
Naji-Azimi, Z., J. Renaud, A. Ruiz, M. Salari. 2012. A covering tour approach to the location of satellite distribution centers to supply humanitarian aid. European Journal of Operational Research 222(3) 596-605.

Narasimhan, S., H. Pirkul, D.A. Schilling. 1992. Capacitated emergency facility siting with multiple levels of backup. Annals of Operations Research 40(1) 323-337.

Natarajan, K.V., J.M. Swaminathan. 2014. Inventory Management in Humanitarian Operations: Impact of Amount, Schedule, and Uncertainty in Funding. Manufacturing \& Service Operations Management 16(4) 595-603.

Nigmatulina, K.R., R.C. Larson. 2009. Living with influenza: Impacts of government imposed and voluntarily selected interventions. European Journal of Operational Research 195(2) 613-627.

Ng, M., S.T. Waller. 2010. Reliable evacuation planning via demand inflation and supply deflation. Transportation Research: Part E 46(6) 1086-1094.

Nolz, P.C., F. Semet, K.F. Doerner. 2011. Risk approaches for delivering disaster relief supplies. OR Spectrum 33(3) 543-569.

Noyan, N. 2012. Risk-averse two-stage stochastic programming with an application to disaster management. Computers \& Operations Research 39(3) 541-559.

Oloruntoba, R. 2010. An analysis of the Cyclone Larry emergency relief chain: Some key success factors. International Journal of Production Economics 126(1) 85-101.

Oloruntoba, R., R. Gray. 2006. Humanitarian aid: an agile supply chain?. Supply Chain Management: An International Journal 11(2) 115-120.

Opasanon, S., E. Miller-Hooks. 2009. The Safest Escape problem. Journal of the Operational Research Society 60 1749-1758.

Osei-Bryson, K-M and A. Joseph, 2009. Editorial. Computers and Operations research 36 (1) 1-1.

Özdamar, L. 2011. Planning helicopter logistics in disaster relief. OR Spectrum 33(3) 655-672.

Özdamar, L., E. Ekinci, B. Küçükyazici. 2004. Emergency Logistics Planning in Natural Disasters. Annals of Operations Research 129(1-4) 217-245.

Özdamar, L., O. Demir. 2012. A hierarchical clustering and routing procedure for large scale disaster relief logistics planning. Transportation Research: Part E 48(3) 591-602.

Papamichail, K.N., French, S., 1999. Generating feasible strategies in nuclear emergencies-a constraint satisfaction problem. Journal of the Operational Research Society 50 (6) 617-626.

Papamichail, K.N., S. French. 2005. Design and evaluation of an intelligent decision support system for nuclear emergencies. Decision Support Systems 41(1) 84-111.

Paul, J.A., G. Hariharan. 2012. Location-allocation planning of stockpiles for effective disaster mitigation. Annals of Operations Research 196(1) 469-490.

Passos, A.C., M.G. Teixeira, K.C. Garcia, A.M. Cardoso, L.F. A.M. Gomes. 2014. Using the TODIMFSE method as a decision-making support methodology for oil spill response. Computers \& Operations Research 42 40-48. 
Peeta, S., F.S. Salman, D. Gunnec, K. Viswanath. 2010. Pre-disaster investment decisions for strengthening a highway network. Computers \& Operations Research 37(10) 1708-1719.

Peng, M., Y. Peng, H. Chen. 2014. Post-seismic supply chain risk management: A system dynamics disruption analysis approach for inventory and logistics planning. Computers \& Operations Research 42 14-24.

Pérez-Villalonga, F., J. Salmerón, K. Wood. 2008. Dynamic evacuation routes for personnel on a naval ship. Naval Research Logistics 55(8) 785-799.

Pidd, M., F.N. de Silva, R.W. Eglese. 1996. A simulation model for emergency evacuation. European Journal of Operational Research 90 (3) 413-419.

Pinker, E.J. 2007. An Analysis of Short-Term Responses to Threats of Terrorism. Management Science 53(6) 865-880.

Preece, G., D. Shaw, H. Hayashi. 2013. Using the Viable System Model (VSM) to structure information processing complexity in disaster response. European Journal of Operational Research 224(1) 209-218.

Psaraftis, H.N., G.G. Tharakan, A. Ceder. 1986. Optimal Response to Oil Spills: The Strategic Decision Case. Operations Research 34(2) 203-217.

Psaraftis, H.N., B.O. Ziogas. 1985. A Tactical Decision Algorithm for the Optimal Dispatching of Oil Spill Cleanup Equipment. Management Science 31(12) 1475-1491.

Qin, J., Y. Xing, S. Wang, K. Wang, S.S. Chaudhry. 2012. An inter-temporal resource emergency management model. Computers \& Operations Research 39(8) 1909-1918.

Qiu, J., Z. Wang, X. Ye, L. Liu, L. Dong. 2014. Modeling method of cascading crisis events based on merging Bayesian Network. Decision Support Systems 62 94-105.

Rachaniotis, N.P., T.K. Dasaklis, C.P. Pappis. 2012. A deterministic resource scheduling model in epidemic control: A case study. European Journal of Operational Research 216(1) 225-231.

Rakes, T.R., J.K. Deane, L.P. Rees, G.M. Fetter. 2014. A decision support system for post-disaster interim housing. Decision Support Systems 66 160-169.

Ramsey Jr., F.A. 1958. Damage assessment systems and their relationship to post-nuclear-attack damage and recovery. Naval Research Logistics 5(3) 199-219.

Ratha, S., W.J. Gutjahra. 2014. A math-heuristic for the warehouse location-routing problem in disaster relief. Computers \& Operations Research 42 25-39.

Rawlsr, C.G., M.A. Turnquist. 2010. Pre-positioning of emergency supplies for disaster response. Transportation Research: Part B 44(4) 521-534.

Rawls, C.G., M.A. Turnquist. 2011. Pre-positioning planning for emergency response with service quality constraints. OR Spectrum 33(3) 481-498.

Regnier, E. 2008. Public Evacuation Decisions and Hurricane Track Uncertainty. Management Science 54(1) 16-28.

Rennemo, S. J., K.F. Rø, L.M. Hvattum, G. Tirado. 2014. A three-stage stochastic facility routing model for disaster response planning. Transportation Research: Part E 62 116-135. 
Riddington, G., M. Beck, J. Cowie. 2004. Evaluating train protection systems. Journal of the Operational Research Society 55(6) 606- 613.

Rivas, J.R., D.F. Rudd. 1975. Man-Machine Synthesis of Disaster-Resistant Operations. Operations Research 23(1) 2-21.

Rodon, J., J.F. Maria Serrano, C. Giménez. 2012. Managing cultural conflicts for effective humanitarian aid. International Journal of Production Economics 139(2) 366-376.

Rodríguez, J.T., B. Vitoriano, J. Montero, V. Kecman. 2011. A disaster-severity assessment DSS comparative analysis. OR Spectrum 33(3) 451-479.

Rodríguez, J.T., B. Vitoriano, J. Montero. 2012. A general methodology for data-based rule building and its application to natural disaster management. Computers \& Operations Research 39(4) 863873.

Rottkemper, B., K. Fischer, A. Blecken, C. Danne. 2011. Inventory relocation for overlapping disaster settings in humanitarian operations. OR Spectrum 33(3) 721-749.

Roy, A., J.A. Paul. 2013. Terrorism deterrence in a two country framework: strategic interactions between R\&D, defense and pre-emption. Annals of Operations Research 211(1) 399-432.

Rungta, M., G.J. Lim, M.R. Baharnemati. 2012. Optimal egress time calculation and path generation for large evacuation networks. Annals of Operations Research 201(1) 403-421.

Saadatseresht, M., A. Mansourian, M. Taleai. 2009. Evacuation planning using multiobjective evolutionary optimization approach. European Journal of Operational Research 198(1) 305-314.

Salmeron J., A. Apte. 2010. Stochastic optimization for natural disaster asset prepositioning. Production and Operations Management 19(5) 561-574.

Sampson, A.R., R.L. Smith. 1982. Assessing Risks Through the Determination of Rare Event Probabilities. Operations Research 30(5) 839-866.

Scaparra, M.P., R.L. Church. 2008. An exact solution approach for the interdiction median problem with fortification. European Journal of Operational Research 189(1) 76-92.

Scholten, K., P. Scott, B. Fynes. 2014. Mitigation Processes - Antecedents for building supply chain resilience. Supply Chain Management: An International Journal 19(2) 211-228.

Shan, X., J. Zhuang. 2013. Subsidizing to disrupt a terrorism supply chain-a four-player game. Journal of the Operational Research Society 65 1108-1119.

Shan, X., J. Zhuang. 2013. Hybrid defensive resource allocations in the face of partially strategic attackers in a sequential defender-attacker game. European Journal of Operational Research 228(1) 262-272.

Shen, M., M. Carswell, R. Santhanam, K. Bailey. 2012. Emergency management information systems: Could decision makers be supported in choosing display formats?. Decision Support Systems 52(2) 318-330.

Sherali, H.D., T.B. Carter. 1991. A location-allocation model and algorithm for evacuation planning under hurricane/flood conditions. Transportation Research: Part B 25(6) 439-452.

Sheu, J.B. 2007. An emergency logistics distribution approach for quick response to urgent relief demand in disasters. Transportation Research: Part E 43(6) 667-709. 
Sheu, J.B. 2010. Dynamic relief-demand management for emergency logistics operations under largescale disasters. Transportation Research: Part E 46(1) 1-17.

Sheu, J.B. 2014. Post-disaster relief-service centralized logistics distribution with survivor resilience maximization. Transportation Research: Part B 68 288-314.

Sheu, J.B., C. Pan. 2014. A method for designing centralized emergency supply network to respond to large-scale natural disasters. Transportation Research: Part B 67 284-305.

Snediker, D.E., A.T. Murray, T.C. Matisziw. 2008. Decision support for network disruption mitigation. Decision Support Systems 44(4) 954-969.

Sodhi, M.S., C.S. Tang. 2013. Buttressing Supply Chains against Floods in Asia for Humanitarian Relief and Economic Recovery. Production and Operations Management 23(6) 938-950.

Starr, M.K., L.N. Van Wassenhove. 2014. Introduction to the Special Issue on Humanitarian Operations and Crisis Management. Production and Operations Management 23(6) 925-937.

Srinivasa, A.V., Wilhelm, W.E., 1997. A procedure for optimizing tactical response in oil spill cleanup operations. European Journal of Operational Research 102(3) 554-574

Stepanov, A., J. MacGregor Smith. 2009. Multi-objective evacuation routing in transportation networks. European Journal of Operational Research 198(2) 435-446.

Sun, L., G.W. DePuyr, G.W. Evans. 2013. Multi-objective optimization models for patient allocation during a pandemic influenza outbreak. Computers \& Operations Research 51 350-359.

Tamura, H., K. Yamamoto, S. Tomiyama, I. Hatono. 2000. Modeling and analysis of decision making problem for mitigating natural disaster risks. European Journal of Operational Research 122(2) 461-468.

Taskin, S., E.J. Lodree Jr. 2011. A Bayesian decision model with hurricane forecast updates for emergency supplies inventory management. Journal of the Operational Research Society 621098 1108.

Tatham, P., G. Kovács. 2010. The application of "swift trust" to humanitarian logistics. International Journal of Production Economics 126(1) 35-45.

Tinsley, C.H., R.L. Dillon, M.A. Cronin. 2012. How Near-Miss Events Amplify or Attenuate Risky Decision Making. Management Science 58(9) 1596-1613.

Toyasaki, F., T. Wakolbinger. 2014. Impacts of earmarked private donations for disaster fundraising. Annals of Operations Research 221(1) 427-447.

Trautsamwieser, A., M. Gronalt, P. Hirsch. 2011. Securing home health care in times of natural disasters. OR Spectrum 33(3) 787-813.

Tuydes-Yaman, H., A. Ziliaskopoulos. 2014. Modeling demand management strategies for evacuations. Annals of Operations Research 217(1) 491-512.

Tzeng, G.H., H.J. Cheng, T.D. Huang. 2007. Multi-objective optimal planning for designing relief delivery systems. Transportation Research: Part E 43(6) 673-686.

Uchida, K. 2012. A model evaluating effect of disaster warning issuance conditions on "cry wolf syndrome" in the case of a landslide. European Journal of Operational Research 218(2) 530-537. 
Valdmanis, V., P. Bernet, J. Moises. 2010. Hospital capacity, capability, and emergency preparedness. European Journal of Operational Research 207(3) 1628-1634.

Van Baalena, P.J., P.C. Van Fenema. 2009. Instantiating global crisis networks: The case of SARS. Decision Support Systems 47(4) 277-286.

Van Wassenhove, L.N. 2006. Humanitarian aid logistics: supply chain management in high gear. Journal of the Operational Research Society 57 475-489.

Vanajakumari, M., S. Kumar, S. Gupta. 2016. An Integrated Logistic Model for Predictable Disasters. Production and Operations Management.

Wang, H., L. Du, S. Ma. 2014. Multi-objective open location-routing model with split delivery for optimized relief distribution in post-earthquake. Transportation Research: Part E 69 160-179.

Wex, F., G. Schryen, S. Feuerriegel, D. Neumann. 2013. Emergency response in natural disaster management: Allocation and scheduling of rescue units. European Journal of Operational Research 235(3) 697-708.

Whybark, D.C., 2007. Issues in managing disaster relief inventories. International Journal of Production Economics 108(1-2) 228-235.

Wikipedia. Retrieved November 17, 2015,

(https://en.wikipedia.org/wiki/List_of_major_power_outages )

Widberg, J. 1989. Operational threat assessments for civil defense planning. European Journal of Operational Research 43(3) 342-349.

Wild, N., L. Zhou. 2011. Ethical procurement strategies for International Aid Non-Government Organisations. Supply Chain Management: An International Journal 16(2) 110-127.

Wilhelm, W.E., Srinivasa, A.V., 1996. A strategic, area-wide contingency planning model for oil spill cleanup operations with application demonstrated to the Galveston Bay Area. Decision Sciences 27(4) 767-799.

Wilhelm, W.E., A.V. Srinivasa. 1997. Prescribing Tactical Response for Oil Spill Clean Up Operations. Management Science 43(3) 386-402.

Wilson, D.T., G.I. Hawe, G. Coates, R.S. Crouch. 2013. A multi-objective combinatorial model of casualty processing in major incident response. European Journal of Operational Research 230(3) 643-655.

Wolf, F.G. 2001. Operationalizing and testing normal accident theory in petrochemical plants and refineries. Production and Operations Management 10(3) 292-305.

Xiang, Y., J. Zhuang. 2016. A medical resource allocation model for serving emergency victims with deteriorating health conditions. Annals of Operations Research 236(1) 177-196

Xie, C., D.Y. Lin, S.T. Waller. 2010. A dynamic evacuation network optimization problem with lane reversal and crossing elimination strategies. Transportation Research: Part E 46(3) 295-316.

Yan, S., Y.L. Shih. 2009. Optimal scheduling of emergency roadway repair and subsequent relief distribution. Computers \& Operations Research 36(6) 2049-2065. 
Yi, W., A. Kumar. 2007. Ant colony optimization for disaster relief operations. Transportation Research: Part E 43(6) 660-672.

Yi, W., L. Özdamar. 2007. A dynamic logistics coordination model for evacuation and support in disaster response activities. European Journal of Operational Research 179(3) 1177-1193.

Yoon, S.W., J.D. Velasquez, B.K. Partridge, S.Y. Nof. 2008. Transportation security decision support system for emergency response: A training prototype. Decision Support Systems 46(1) 139-148.

Yu, L., K.K. Lai. 2011. A distance-based group decision-making methodology for multi-person multicriteria emergency decision support. Decision Support Systems 51(2) 307-315.

Zeng, Y., R. Xiao. 2014. Modeling of cluster supply network with cascading failure spread and its vulnerability analysis. International Journal of Production Research 52(20) 6938-6953.

Zheng, Y.J., H.F. Ling, H.H. Shi, H.S. Chen, S.Y. Chen. 2014. Emergency railway wagon scheduling by hybrid biogeography-based optimization. Computers \& Operations Research 43 1-8.

Zhuang, J., V.M. Bier. 2007. Balancing Terrorism and Natural Disasters-Defensive Strategy with Endogenous Attacker Effort. Operations Research 55(5) 976-991.

Zobel, C.W. 2011. Representing perceived tradeoffs in defining disaster resilience. Decision Support Systems 50(2) 394-403.

Zobel, C.W., L. Khansa. 2014. Characterizing multi-event disaster resilience. Computers \& Operations Research 42 83-94. 